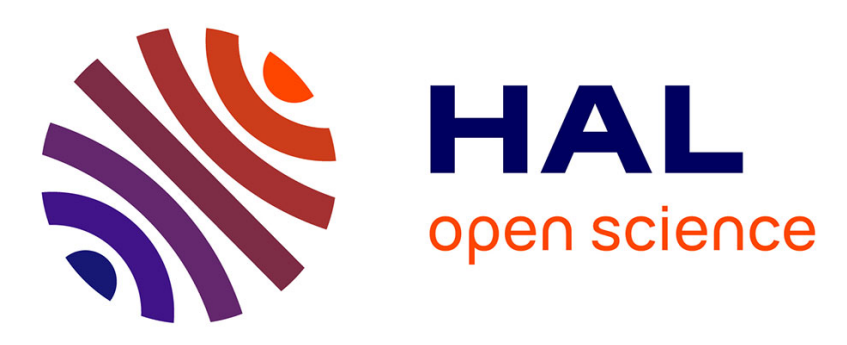

\title{
Total Syntheses of Two bis-Allylic-Deuterated DHA Analogues
}

Mélissa Rosell, Maxime Villa, Thierry Durand, Jean-Marie Galano, Joseph Vercauteren, Céline Crauste

\section{- To cite this version:}

Mélissa Rosell, Maxime Villa, Thierry Durand, Jean-Marie Galano, Joseph Vercauteren, et al.. Total Syntheses of Two bis-Allylic-Deuterated DHA Analogues. Asian Journal of Organic Chemistry, 2017, 6 (3), pp.322 - 334. 10.1002/ajoc.201600565 . hal-01622325

\section{HAL Id: hal-01622325 \\ https://hal.umontpellier.fr/hal-01622325}

Submitted on 2 Jun 2021

HAL is a multi-disciplinary open access archive for the deposit and dissemination of scientific research documents, whether they are published or not. The documents may come from teaching and research institutions in France or abroad, or from public or private research centers.
L'archive ouverte pluridisciplinaire HAL, est destinée au dépôt et à la diffusion de documents scientifiques de niveau recherche, publiés ou non, émanant des établissements d'enseignement et de recherche français ou étrangers, des laboratoires publics ou privés. 



\title{
Total Syntheses of Two bis-Allylic-Deuterated DHA Analogues
}

\author{
Mélissa Rosell, Maxime Villa, Thierry Durand, Jean-Marie Galano, Joseph Vercauteren, and \\ Céline Crauste ${ }^{*[a]}$
}

Abstract: The deuteration of polyunsaturated fatty acids (PUFAs) at their bis-allylic positions is known to limit harmful lipid peroxidation, which leads to the damage of cell membranes. Therefore, to impede toxic lipid peroxidation in retina tissue, we have designed and synthesized two deuterated analogues of docosahexaenoic acid (DHA; $222: 6, n-3)$, which is the main lipid constituent of retina membranes. To avoid its oxidative degradation into toxic carboxyethylpyrrole (CEP) adducts, whilst preserving enzymatic metaboliza- tion into a healthy neuroprotectine derivative (NPD1), deuterium was incorporated at specific 6- and 6,9-bis-allylic positions. A convergent synthetic strategy, based on a Wittig olefination, was developed to obtain both deuterated DHA species. Common aldehyde intermediates were synthesized from another PUFA, eicosapentaenoic acid (EPA; C20:5, n-3). Deuterium atoms were introduced through either the reduction of an ester with a deuterated reagent or a nucleophilic reaction with deuterated paraformaldehyde.

\section{Introduction}

Docosahexaenoic acid (DHA; $\mathrm{C} 22: 6, n-3)$, a polyunsaturated fatty acid (PUFA) that is highly enriched in the membranes of retina and brain tissue, is necessary for brain and retina development in infants ${ }^{[1]}$ and for the retention of normal function in adults. ${ }^{[2]}$ Like many PUFAs, DHA supplementation has been widely studied and has been shown to have a positive effect on several inflammatory diseases. ${ }^{[3]}$ Furthermore, DHA supplementation is also considered to be an effective strategy for the prevention of cardiovascular disease $\mathrm{e}^{[4]}$ and neurological disorders. ${ }^{[5]}$ However, the effect of DHA on oxidative damage in retina and brain pathologies remains controversial. Conflicting data on DHA supplementation (in clinical studies or in animal models) have shown either beneficial ${ }^{[6]}$ or no effect ${ }^{[7]}$ on the impedance of retina degeneration, thereby leading to the hypothesis that DHA activity may also depends on DHA metabolites and, thus, on patient metabolism. In fact, because of its chemical structure and the presence of six double bonds and five highly oxidizable bis-allylic positions, this lipid derivative is susceptible to enzymatic and non-enzymatic oxidations. In both cases, conversion occurs through the abstraction of a hydrogen atom from one of the bis-allylic position, as initiated

\footnotetext{
[a] M. Rosell, M. Villa, Dr. T. Durand, Dr. J.-M. Galano, Prof. J. Vercauteren, Dr. C. Crauste

Institut des Biomolécules Max Mousseron IBMM, UMR5247 CNRS-UM-ENSCM

Faculté de Pharmacie

15 avenue C. Flahault, BP 14491

34093 Montpellier Cedex 5 (France)

Fax: (+ 33) 4-11-75-95-66

E-mail: celine.crauste@umontpellier.fr

$\square$ Supporting information for this article can be found under: http://dx.doi.org/10.1002/ajoc.201600565.
}

either by reactive oxygen species ( $\mathrm{ROS}$; ${ }^{\circ} \mathrm{OOR},{ }^{\circ} \mathrm{OR},{ }^{\circ} \mathrm{OH}$, or $\mathrm{NO}_{2}{ }^{\circ}$ ) or by specific enzymes, and leads to an unstable pentadienyl radical that can rearrange in different ways to form cyclic or non-cyclic metabolites. As a result, enzymatic and non-enzymatic conversions of DHA can lead to a large variety of bioactive "mediators" (neuroprotectin, resolvin, neuroprostane, neurofurane, neuroketal, etc.), depending on the position of the first abstracted hydrogen atom, the enzyme involved, the partial pressure of oxygen, and the importance of oxidative stress. ${ }^{[8]}$

There is recent compelling evidence that non-enzymatic and enzymatic oxidized metabolites of DHA may contribute to its positive as well as negative biological activities (in vitro and in vivo). These cell mediators, signaling molecules, and biologically active secondary metabolites can either be protective or toxic towards the cells. For example, neuroprotectin D1 (NPD1), which is biosynthesized by 15-lipoxygenase (15-LOX) from enzymatic bis-allylic hydrogen abstraction at the 15 position (followed by epoxide rearrangement and hydrolysis), has shown interesting antioxidant properties in retina cells, ${ }^{\left[{ }^{[9]}\right.}$ antiinflammatory activity, ${ }^{[10]}$ and neuroprotective properties ${ }^{[11]}$ (Scheme 1). Coming from a non-enzymatic pathway, 4- $\mathrm{F}_{4 \mathrm{t}}$-neuroprostane is generated by the free-radical oxidation of DHA and has shown powerful antiarrhythmic activity. ${ }^{[12]}$ Unfortunately, the ROS-initiated oxidation of PUFAs in cell membranes also leads to lipid peroxides, DNA deterioration, and, thus, is involved in carcinogenesis. The end-products of DHA peroxidation include small electrophilic carbonyl species, such as trans4-hydroxy-hex-2-enal (4-HHE). Such a reactive aldehyde is prone to nucleophilic attack by cellular components (DNA or proteins), thereby causing irreversible damage to the cells, ${ }^{[13]}$ yet it is surprisingly also responsible for antioxidant defenses through the activation of the Nfr2/keap1 pathway in the 


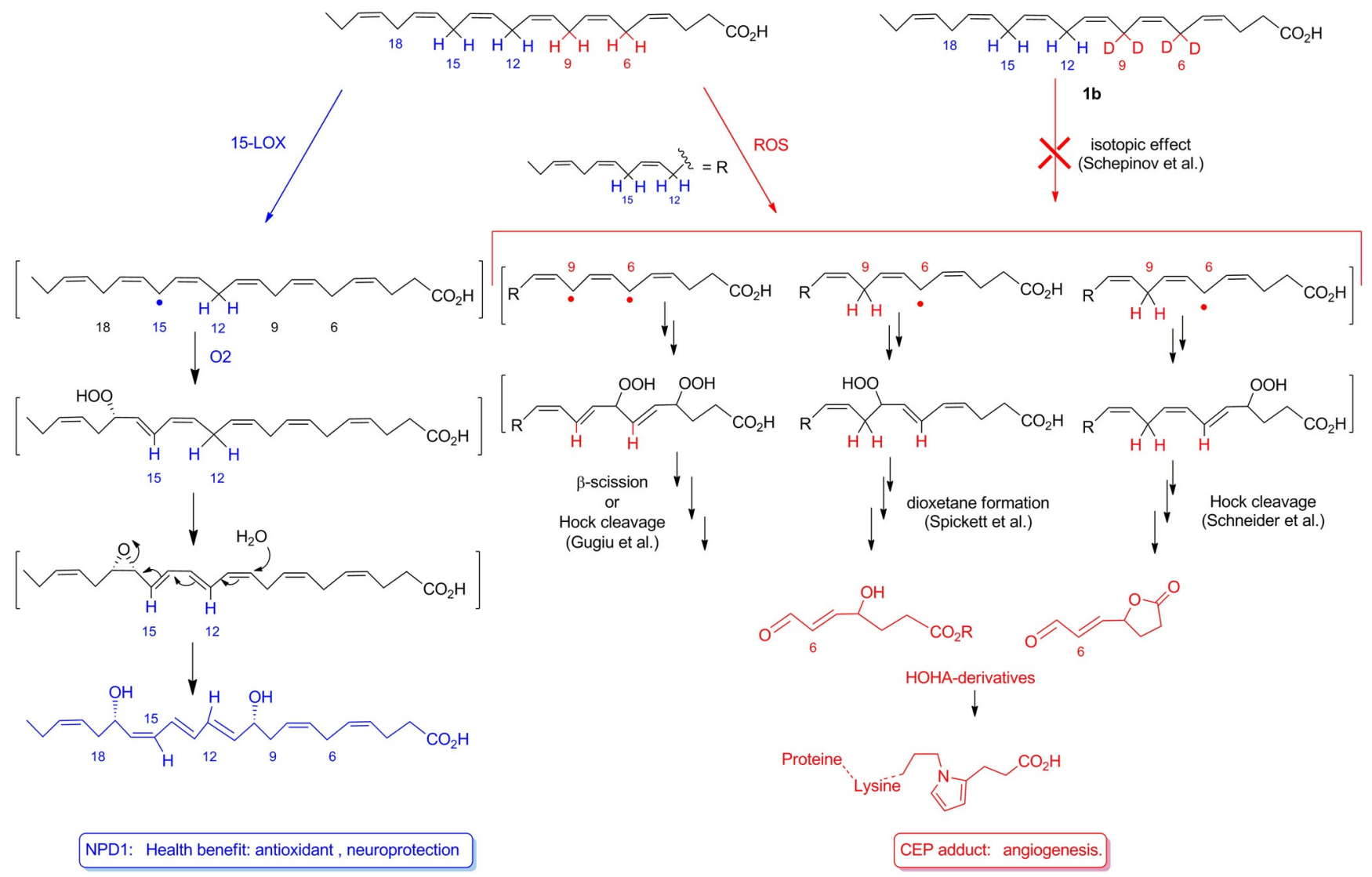

Scheme 1. DHA oxidation yields toxic or beneficial metabolites for retina cells.

cells. ${ }^{[14]}$ In an analogous manner to the formation of trans-4-hydroxy-2-nonenal (4-HNE) through $n-6$ lipid peroxidation, ${ }^{[15]} 4$ hydroxy-7-oxo-hept-5-enoic acid ( $\mathrm{HOHA}$; Scheme 1) is generated from DHA oxidation, which is, most likely, initiated by $\mathrm{H}$-abstraction at the 6- or, 6- and 9-positions. Protein lysyl $\varepsilon$-amino residues readily add onto such $\mathrm{HOHA}$ compounds (free acid, lactone, or even phosphatidylethanolamine derivatives) to generate 2- $\omega$-carboxyethylpyrroles (CEP adducts), which induce angiogenesis in the retina, a pathological development that is associated with the advanced stages of age-related macular degeneration (AMD). ${ }^{[16]}$

Recently, Shchepinov and co-workers ${ }^{[17]}$ prepared analogues of linoleic and linolenic acids that were deuterated at their bisallylic sites and found that they slowed down bis-allylic abstraction $\left(k_{\mathrm{H}} / k_{\mathrm{D}}=23\right.$ in the case of $\left(11,11-\mathrm{D}_{2}\right)$-linoleic acid) during the tocopherol-mediated peroxidation process. This result was attributed to the primary kinetic deuterium isotope effect, which was linked to the replacement of two hydrogen atoms on those positions. ${ }^{[17 \mathrm{~d}]}$ This work showed that such deuterated PUFAs were much more reluctant to undergo oxidation than nondeuterated lipids, but were also able to protect adjacent nondeuterated PUFAs from lipid peroxidation.

As part of our ongoing interest in the development of DHA conjugates for applications in pharmacological issues related to the treatment of retina pathologies, ${ }^{[18]}$ we applied this strategy to the DHA and herein, we report the first total syntheses of two DHA analogues that were regioselectively deuterated at the 6- and 6,9-bis-allylic positions ( $\mathbf{1} \mathbf{a}$ and $\mathbf{1} \mathbf{b}$, respectively; Scheme 2). Such compounds could, on the one hand, increase the protection of retina cell membranes against peroxidation by impeding the formation of toxic HOHA derivatives and, thus, of the deleterious CEP adducts (Scheme 1), whilst on the other hand, retain their enzymatic metabolization into the beneficial NPD1, owing to the presence of more abstractable hydrogen atoms at the required 15- and 12-positions (Scheme 1). Moreover, in these specific deuterated DHA analogues, the oxidation reaction may be oriented to selectively target the bis-allylic positions, thereby leading to a restricted number of biological mediators. Therefore, these compounds would be efficient biological tools for better identifying which DHA metabolites are involved in health benefits and which have toxic effects.

\section{Results and Discussion}

Deuterium-labeled compounds can be used in a wide range of applications and their synthesis has been extensively studied. The incorporation of deuterium through H/D exchange has been achieved by using iridium or ruthenium complexes on aliphatic or aromatic substrates, ${ }^{[19]}$ and even at the allylic position after alkene isomerization. ${ }^{[20]}$ However, these methods were not designed to selectively incorporate deuterium atoms at the bis-allylic positions of DHA. 


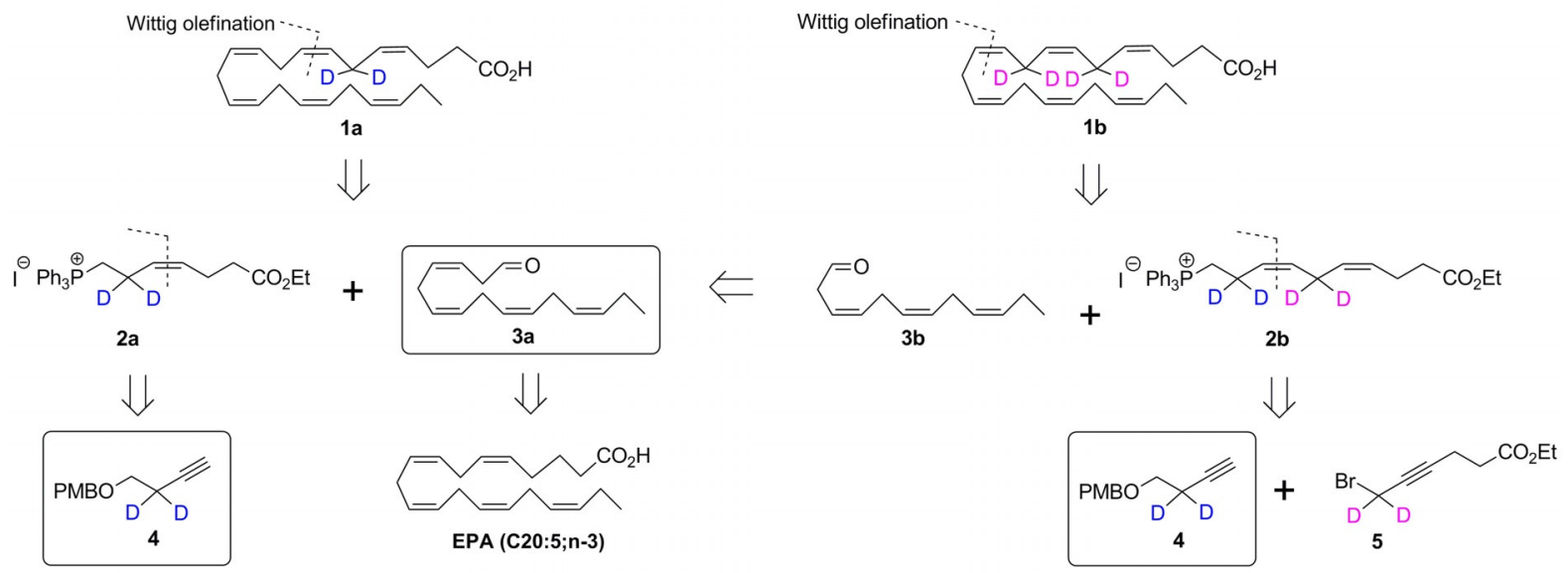

Scheme 2. Retrosynthetic analysis of (6,6- $\left.\mathrm{D}_{2}\right)-\mathrm{DHA}$ and $\left(6,6,9,9-\mathrm{D}_{4}\right)-\mathrm{DHA}$ through common intermediates 4 and $3 \mathrm{a}$.

To access (6,6-D $)$-DHA (1 a) and (6,6,9,9-D $)$-DHA (1 b), we developed a convergent synthetic strategy based on a Wittig reaction for the formation of a double bond at the 7- or 10-positions of the DHA skeleton (Scheme 2). Aldehyde $\mathbf{3} \mathbf{a}$ and alkyne $\mathbf{4}$ were identified as common intermediates in the retrosyntheses of both deuterated PUFAs. Indeed, compound 1 a could be obtained from a Wittig olefination reaction between compound $\mathbf{3} \mathbf{a}$ and the ylide that is generated from phosphonium salt $\mathbf{2}$ a. Aldehyde $\mathbf{3}$ a could also serve as a precursor to aldehyde $\mathbf{3} \mathbf{b}$, which could be involved in the key Wittig coupling reaction for the synthesis of compound $\mathbf{1} \mathbf{b}$.

Aldehyde 3 a could be obtained from the natural PUFA eicosapentaenoic acid (EPA; $C 20: 5, n-3)$, which would allow us to directly incorporate the remaining four double bonds into the C22 lipid skeleton. Then, deuterium atoms could be incorporated during the syntheses of phosphonium salts $\mathbf{2} \mathbf{a}$ and $\mathbf{2} \mathbf{b}$, which could occur from a common deuterated alkyne (synthon 4). This synthon could either be deprotonated and involved in a reaction with oxetane to give compound $\mathbf{2 a}$, or coupled with deuterated propargylic bromide derivative synthon $\mathbf{5}$ to obtain the second phosphonium salt (2 b).

\section{Synthesis of Deuterated Synthons 4 and 5}

Two methods of deuteration were employed to produce deuterated synthons $\mathbf{4}$ and $\mathbf{5}$. The synthesis of synthon $\mathbf{4}$ (Scheme 3) started with the protection of the methylglycolate with a $p$-methoxybenzyl (PMB) group under acidic conditions to give compound 6 . Reduction ${ }^{[21]}$ of the ester group by using $\mathrm{LiAID}_{4}$ afforded deuterated intermediate 7 , which was converted into the corresponding tosyl ester (8). Finally, nucleophilic substitution with the lithium acetylide ethylenediamine complex $(\mathrm{LiCCH} \cdot \mathrm{EDA})^{[22]}$ led to the desired deuterated terminal alkyne (4) in $61 \%$ yield in four steps.

A different procedure was used to introduce the deuterium atoms into synthon 5 (Scheme 4). After the protection of 5pentyn-1-ol with a tetrahydropyran (THP) group, ${ }^{[23]}$ terminal alkyne 9 was deprotonated by using a Grignard reagent. Then, nucleophilic attack on deuterated paraformaldehyde afforded alcohol 10, which was further converted into the correspond-

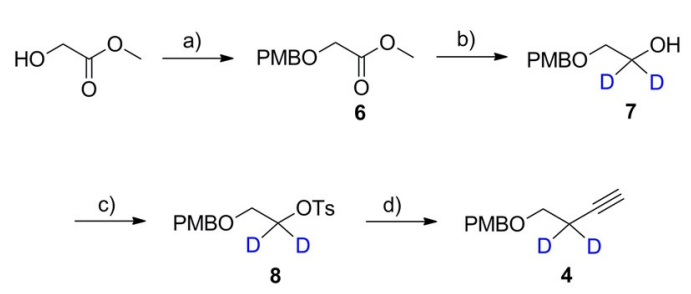

Scheme 3. Synthesis of deuterated alkyne 4: a) PMBTCA, CSA, $\mathrm{CH}_{2} \mathrm{Cl}_{2}, \mathrm{RT}$, $96 \%$ yield; b) $\mathrm{LiAlD}_{4}, \mathrm{Et}_{2} \mathrm{O}, 0{ }^{\circ} \mathrm{C}, 91 \%$ yield; c) $\mathrm{TsCl}_{1} \mathrm{Et}_{3} \mathrm{~N}, \mathrm{CH}_{2} \mathrm{Cl}_{2}, 0^{\circ} \mathrm{C}, 97 \%$ yield; d) LiCCH.EDA, DMSO, $10^{\circ} \mathrm{C}$ to RT, $77 \%$ yield. PMBTCA $=p$-methoxybenzyl trichloroacetimidate, $\mathrm{Ts}=p$-methylphenylsulfonyl, $\mathrm{CSA}=$ camphorsulfonic acid.

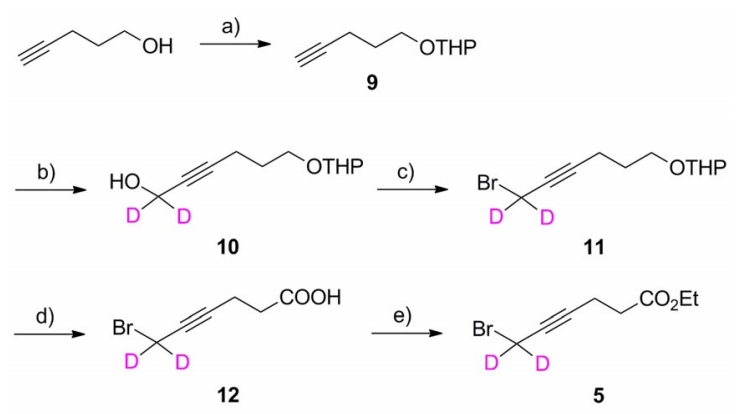

Scheme 4. Synthesis of deuterated bromide 5: a) DHP, PTSA, $\mathrm{CH}_{2} \mathrm{Cl}_{2}, \mathrm{RT}, 91 \%$ yield; b) EtMgBr then $\left(\mathrm{CD}_{2} \mathrm{O}\right)_{n}$, THF, reflux, $86 \%$ yield; c) $\mathrm{CBr}_{4}, \mathrm{PPh}_{3}$, imidazole, $\mathrm{CH}_{2} \mathrm{Cl}_{2},-40{ }^{\circ} \mathrm{C}, 60 \%$ yield; d) Jones reagent $(2.17 \mathrm{M})$, acetone, $0^{\circ} \mathrm{C}, 87 \%$ yield; e) $\mathrm{H}_{2} \mathrm{SO}_{4}$ (cat.), $\mathrm{EtOH}, 30^{\circ} \mathrm{C}, 90 \%$ yield. $\mathrm{PTSA}=p$-toluenesulfonic acid

ing bromide derivative (11) by using the Appel reagent. Cleavage of the THP group and oxidation were performed at the same time by using Jones conditions to give acid 12. A final Fischer esterification afforded the deuterated propargylic bromide derivative synthon (5) in $37 \%$ yield in five steps.

\section{Synthesis of Phosphonium Salts $2 \mathrm{a}$ and $2 \mathrm{~b}$}

For the syntheses of compounds $\mathbf{2} \mathbf{a}$ and $\mathbf{2} \mathbf{b}$, deuterated alkyne $\mathbf{4}$ was chosen as a common starting material 

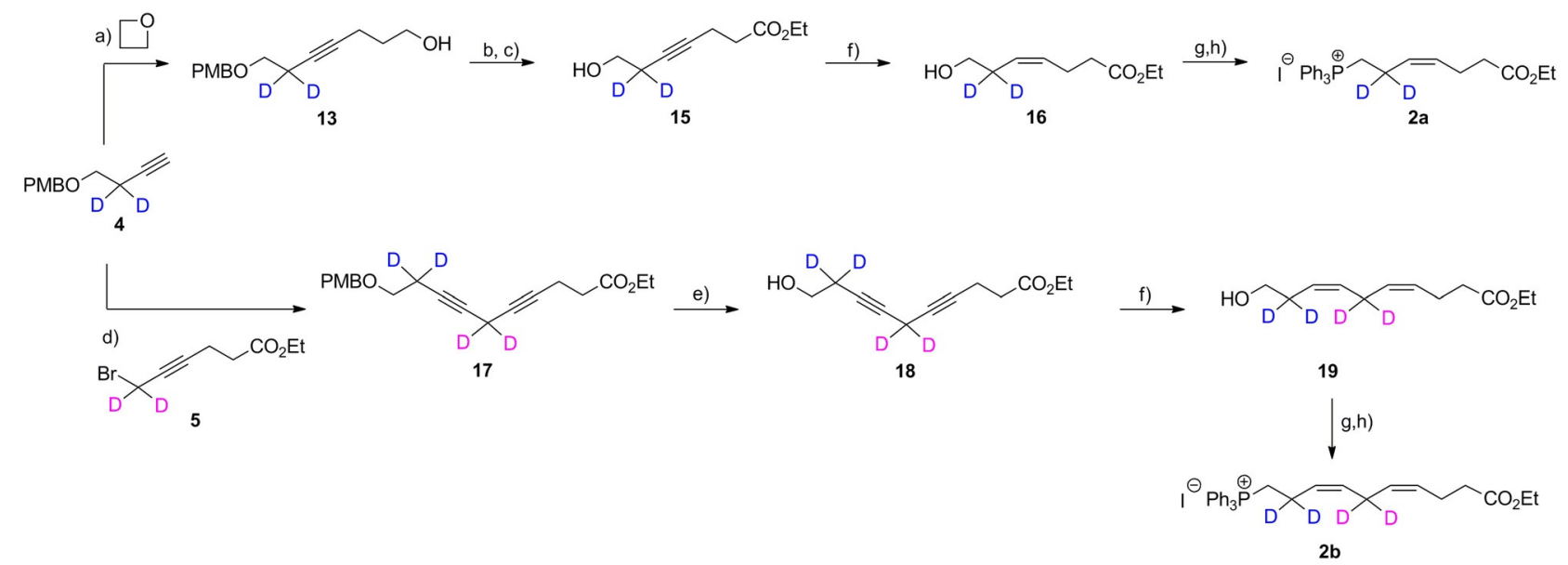

Scheme 5. Synthesis of deuterated phosphonium salts $2 \mathrm{a}$ and $\mathbf{2} \mathbf{b}$ : a) $n \mathrm{BuLi}, \mathrm{BF}_{3} \cdot \mathrm{Et}_{2} \mathrm{O}, \mathrm{THF}_{1}-78{ }^{\circ} \mathrm{C}, 79 \%$ yield; b) Jones reagent $(2.17 \mathrm{M})$, acetone, $0{ }^{\circ} \mathrm{C}, 94 \%$ yield; c) $\mathrm{EtOH}, \mathrm{H}_{2} \mathrm{SO}_{4}$ (cat.), $35^{\circ} \mathrm{C}, 86 \%$ yield; d) Cul, Nal, $\mathrm{K}_{2} \mathrm{CO}_{3}, \mathrm{DMF}, \mathrm{RT}, 75 \%$ yield; e) $\mathrm{DDQ}, \mathrm{CH}_{2} \mathrm{Cl}_{2} /$ water, $\mathrm{RT}, 94 \%$ yield; f) P2-Ni, $\mathrm{EDA}, \mathrm{EtOH}, 0{ }^{\circ} \mathrm{C}, 90 \%$ yield ( $6 \%$ over-reduction) for compound 16 and $78 \%$ yield (13\% over-reduction) for compound $19 ; \mathrm{g}) \mathrm{I}_{2}, \mathrm{PPh}_{3}, \mathrm{imidazole} \mathrm{CH}_{2} \mathrm{Cl}{ }_{2},{ }^{\circ} \mathrm{C}$ to $\mathrm{RT}$; h) $\mathrm{PPh}, \mathrm{MeCN}_{3}$ reflux, $87 \%$ yield for compound $\mathbf{2} \mathbf{a}$ and $93 \%$ yield for compound $\mathbf{2} \mathbf{b}$ (over two steps).

(Scheme 5). Our synthesis of compound 2 a began with ringopening of the oxetane after the deprotonation of compound 4 by using $n \mathrm{BuLi}$ in the presence of Lewis acid $\mathrm{BF}_{3} \cdot \mathrm{Et}_{2} \mathrm{O}(79 \%$ yield). ${ }^{[2]}$ Jones oxidation of alcohol 13 afforded acid 14, which was followed by esterification and deprotection of the PMB group. Reduction of alkyne $\mathbf{1 5}$ with the $\mathrm{P} 2-\mathrm{Ni}$ catalytic system ${ }^{[25]}$ (Brown's catalyst; $\mathrm{Ni}(\mathrm{OAc})_{2}$ in the presence of $\mathrm{NaBH}_{4}$ poisoned by ethylenediamine) yielded alkene 16 (90\% yield), with a small amount of over-reduction (6\%). Then, the iodine derivative was obtained from alcohol 16 by using the Appel reagent and was finally transformed into the corresponding phosphonium salt (2a) through nucleophilic displacement with triphenylphosphine.

The synthesis of compound $\mathbf{2} \mathbf{b}$ (Scheme 5) started with the preparation of skipped-diyne unit 17 . The coupling reaction between terminal alkyne 4 and deuterated propargylic bromide $\mathbf{5}$ was achieved by using Caruso conditions in the presence of Cul (75\% yield), ${ }^{[26]}$ and deprotection of the PMB group gave the tetradeuterated skipped-diyne alcohol (18).

To prevent the formation of over-reduced byproducts during the reduction of skipped-diyne 18 into skipped-diene 19, three different hydrogenation reactions ${ }^{[27]}$ were tested and compared: Lindlar catalyst; ${ }^{[28]}$ Rosenmund catalyst; ${ }^{[29]}$ and Brown's catalyst. The proportion of over-reduction was estimated from the integration of the $\mathrm{CH}_{2}-\mathrm{OH}$ signal in the ${ }^{1} \mathrm{H}$ NMR spectrum (Figure 1).

Increasing the number of equivalents of ethylenediamine and decreasing the reaction time and temperature allowed us to limit the formation of the over-reduction side-product to $13 \%$ (the over-reduced side product was removed during the final purification of compound $\mathbf{1} \mathbf{b}$ ) with the P2-Ni catalytic system $(78 \%$ yield). The Lindlar and Rosenmund catalysts afforded higher proportions of the over-reduction side-product (23\% and $32 \%$, respectively; Figure 1) and also suffered from a lack of reproducibility. Finally, phosphonium salt $\mathbf{2} \mathbf{b}$ was synthesized from skipped-diene alcohol 19 in two steps by using similar conditions as for the synthesis of compound $\mathbf{2}$ a.

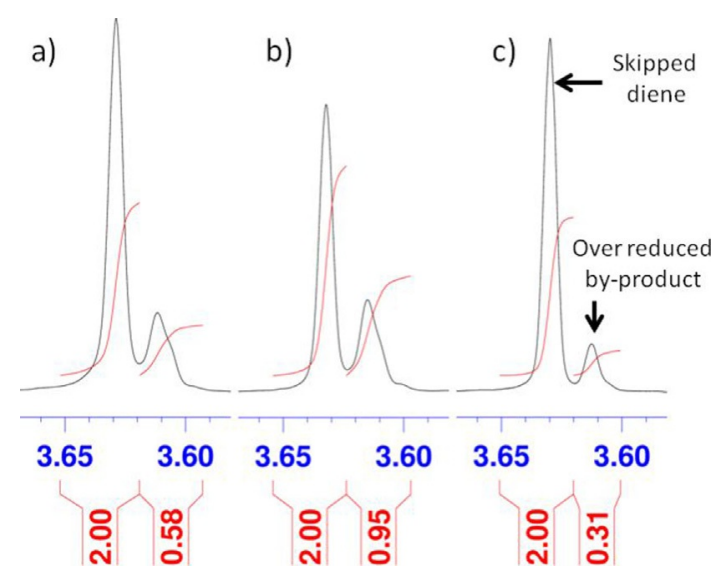

Figure 1. ${ }^{1} \mathrm{H}$ NMR signals of the $\mathrm{CH}_{2}-\mathrm{OH}$ group during the hydrogenation of compound 18. Percentage over-reduction: a) Lindlar catalyst $\left(\mathrm{Pd} / \mathrm{CaCO}_{3}\right.$ poisoned with quinoline), $23 \%$; b) Rosenmund catalyst $\left(\mathrm{Pd} / \mathrm{BaSO}_{4}\right.$, poisoned with quinoline), $32 \%$; c) Brown's catalyst $\left(\mathrm{Ni}(\mathrm{OAC})_{2}\right.$ in the presence of $\mathrm{NaBH}_{4}$ poisoned with ethylenediamine), $13 \%$.

\section{Synthesis of Aldehydes $3 \mathrm{a}$ and $\mathbf{3} \mathrm{b}$}

Aldehydes $\mathbf{3} \mathbf{a}$ and $\mathbf{3} \mathbf{b}$ were prepared from the polyunsaturated fatty acid EPA (Scheme 6). This strategy allowed us to access chemical synthons that already contained three or four (Z) double bonds in their backbones. EPA was extracted from cod liver oil by using a process that was developed to concentrate PUFAs starting from fish oil. ${ }^{[18 b]}$ The synthesis of epoxyester 21 began by treating EPA with $\gamma$-collidine (2,4,6-trimethylpyridine) in the presence of a small excess of $\mathrm{I}_{2}$ (2 equiv), as described by Itoh et al., ${ }^{[30]}$ to give iodolactone intermediate 20. By using such a procedure, epoxide $\mathbf{2 1}$ was obtained in $95 \%$ yield in two steps after opening of the iodolactone. This procedure was preferred to that reported by Jakobsen et al., ${ }^{[31]}$ in which large excesses of $\mathrm{I}_{2}$ (8 equiv), $\mathrm{Kl}$, and $\mathrm{KHCO}_{3}$ were required and which led to a low yield of the product and difficult purification of the iodolactone. Aldehyde $\mathbf{3}$ a was finally ob- 

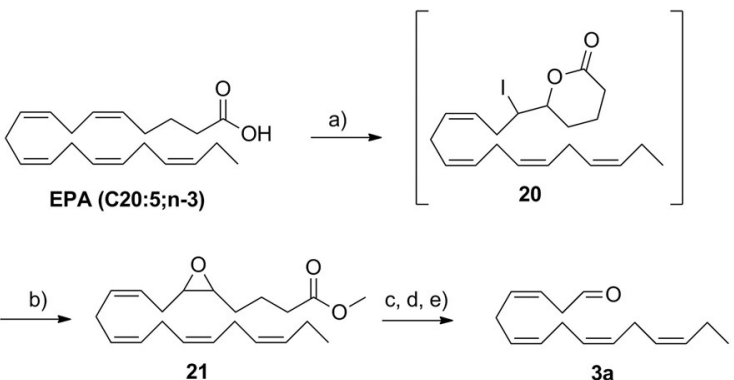

3a
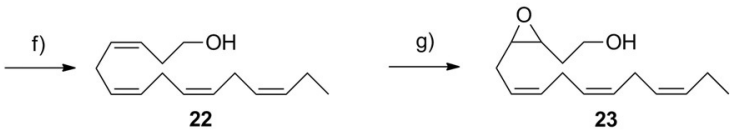

$\stackrel{\mathrm{h}, \mathrm{i}, \mathrm{j})}{\longrightarrow}$

Scheme 6. Synthesis of aldehydes $\mathbf{3} \mathbf{a}$ and $\mathbf{3} \mathbf{b}$ from EPA: a) $\mathrm{I}_{2}, \gamma$-Collidine, $\mathrm{MeCN}, 0^{\circ} \mathrm{C}$; b) $\mathrm{K}_{2} \mathrm{CO}_{3}, \mathrm{MeOH}, \mathrm{RT}, 95 \%$ yield (over two steps); c) $\mathrm{Ac}_{2} \mathrm{O}, \mathrm{AcOH}$, $45^{\circ} \mathrm{C}$; d) $\mathrm{LiOH}$, water/MeOH, RT; e) $\mathrm{NalO}_{4}$, water $/ \mathrm{MeOH}, \mathrm{RT}$, $87 \%$ yield (over three steps); f) $\mathrm{NaBH}_{4}, \mathrm{MeOH}, 0{ }^{\circ} \mathrm{C}, 64 \%$ yield (over four steps from compound 21); g) $\mathrm{VO}(\mathrm{acac})_{2}, t \mathrm{BuOOH}$, toluene, $0{ }^{\circ} \mathrm{C}$ to $\mathrm{RT}, 73 \%$ yield; $\left.\mathrm{h}\right) \mathrm{Ac}_{2} \mathrm{O}$ $\mathrm{AcOH}, 45^{\circ} \mathrm{C}$; i) $\mathrm{LiOH}$, water $/ \mathrm{MeOH}, \mathrm{RT}$; j) $\mathrm{NalO}_{4}$, water $/ \mathrm{MeOH}, \mathrm{RT}, 62 \%$ yield (over three steps). $\mathrm{Ac}_{2} \mathrm{O}=$ acetic anhydride, $\mathrm{AcOH}=$ acetic acid, $\mathrm{VO}$ (a$(\mathrm{cac})_{2}=$ Vanadyl acetylacetonate

tained from compound $\mathbf{2 1}$ in three steps in a one-pot procedure: ${ }^{[32]}$ the epoxide was opened by using acetic anhydride in acetic acid; the resulting acetylated intermediate was saponified to give a vicinal diol; and the diol was oxidized by using sodium periodate $\left(\mathrm{NalO}_{4}\right)$ to afford the desired aldehyde (3a) in $87 \%$ crude yield. This latter compound was used without purification by column chromatography on silica gel because of its susceptibility towards degradation into the corresponding $\alpha, \beta$-unsaturated aldehyde. However, purification by aqueous washing and filtration through Celite ${ }^{\circledR}$ allowed us to isolate the desired aldehyde in high purity (which was necessary for a successful Wittig olefination reaction).

We envisaged a synthesis of aldehyde $\mathbf{3} \mathbf{b}$ from compound $\mathbf{3} \mathbf{a}$ in five steps as described by Wang et al. ${ }^{[33]}$ Thus, the reduction of compound 3 a with $\mathrm{NaBH}_{4}$ afforded homoallylic alcohol 22 , which was treated with vanadyl acetylacetonate $\left(\mathrm{VO}(\mathrm{acac})_{2}\right)$ and $t \mathrm{BuOOH}$ to give intermediate epoxide alcohol 23. Ringopening of the epoxide was first performed with perchloric acid, which led to an unstable triol intermediate that was treated with sodium periodate to promote oxidative cleavage. However, disappointingly, under these conditions, compound $\mathbf{3} \mathbf{b}$ was isolated in unacceptable purity for its use in the Wittig reaction. Thus, we employed the procedure that we previously used to synthesize compound $\mathbf{3} \mathbf{a}$ and optimized the reaction conditions to obtain the desired aldehyde $\mathbf{3} \mathbf{b}$ in high purity from epoxide alcohol 23. Thus, opening of the epoxide and protection of the resulting alcohol by using acetic anhydride, followed by mild saponification with $\mathrm{LiOH}$ and oxidative cleavage, led to aldehyde $3 \mathbf{b}$ ( $62 \%$ crude yield in three step without purification by column chromatography on silica gel). Two determining factors were identified for obtaining the aldehyde (3 b) in acceptable purity: epoxide $\mathbf{2 3}$ had to be used no more than one week after its preparation (because of possible degradation) and the reaction time of the epoxide-opening/acetylation reaction needed to be limited to form only the monoand diacetylated derivatives, because the triacetylated compound appeared to be less reactive towards saponification.

\section{Final Steps in the Synthesis of the Deuterated DHA Analogues}

Both deuterated DHA skeletons were obtained thanks to the key Wittig olefination reaction. During the optimization of the synthesis of the DHA ethyl esters (24a and $\mathbf{2 4}$ b; Scheme 7), we found that several parameters were important for the success and reproducibility of the reaction. As shown in Table 1, the temperature of the reaction must reach room temperature after the addition of both reactants (Table 1, entries 1 and 2). The order of addition also played a significant role: more-reproducible yields were obtained when the aldehyde was poured into the ylide (Table 1, entries 2 and 3). Moreover, increasing the number of equivalents of aldehyde (1.7 equiv) allowed us to slightly improve the reaction yield (Table 1, entries 3 and 4).The final essential parameter for obtaining an acceptable reaction yield was the purity of the aldehyde (Table 1 , entries 5 and 6). As a result, optimized Wittig conditions gave

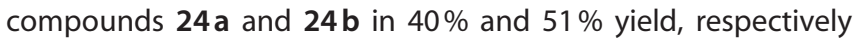
(Table 1, entries 4 and 6). A final saponification step allowed us to obtain $\left(6,6-\mathrm{D}_{2}\right)-\mathrm{DHA}$ ( $\left.1 \mathrm{a}\right)$ in $8.3 \%$ global yield in 17 steps and $\left(6,6,9,9-\mathrm{D}_{4}\right)-\mathrm{DHA}(\mathbf{1} \mathbf{b})$ in $1.5 \%$ overall yield in 26 steps. Both deuterated DHA analogues were purified by using semipreparative HPLC to remove the over-reduced byproducts that were obtained during the hydrogenation step.

\section{Conclusion}

We have reported the first total syntheses of DHA derivatives that were deuterated at specific 6- or 6,9-bis-allylic positions.

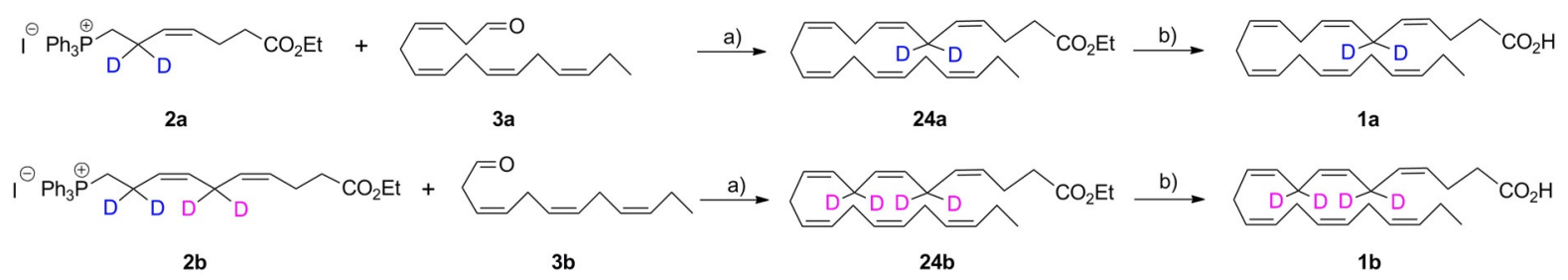

Scheme 7. Final steps to deuterated DHA analogues $\mathbf{1}$ a and $\mathbf{2} \mathbf{b}$ : a) NaHMDS, $-50^{\circ} \mathrm{C}$ to $-20^{\circ} \mathrm{C}$, THF, then compound $3 \mathbf{a}$ or $3 \mathbf{b},-78{ }^{\circ} \mathrm{C}$ to RT, $40 \%$ yield for compound $\mathbf{2}$ a and $51 \%$ yield for compound $\mathbf{2} \mathbf{b}$; b) $\mathrm{LiOH}$, EtOH/water $(1: 1), 60{ }^{\circ} \mathrm{C}, 77 \%$ yield for compound $\mathbf{1}$ a and $84 \%$ yield for compound $\mathbf{1} \mathbf{b}$. 
Table 1. Optimization of Wittig olefination reaction. ${ }^{[a]}$

\begin{tabular}{|lllcc|}
\hline Entry & $T\left[{ }^{\circ} \mathrm{C}\right]$ & Aldehyde (equiv) & Product & Yield [\%] \\
\hline $1^{[\mathrm{b}]}$ & -78 & 0.95 & $\mathbf{2 4 a}$ & 6 \\
$2^{[\mathrm{b}]}$ & -78 to RT & 0.95 & $\mathbf{2 4 a}$ & 12 \\
$3^{[c]}$ & -78 to RT & 0.95 & $\mathbf{2 4} \mathbf{a}$ & 31 \\
$4^{[c]}$ & -78 to RT & 1.7 & $\mathbf{2 4} \mathbf{a}$ & 40 \\
$5^{[c]}$ & -78 to RT & 2 & $\mathbf{2 4} \mathbf{b}$ & $17^{[\mathrm{d}]}$ \\
$6^{[c]}$ & -78 to RT & 1.7 & $\mathbf{2 4} \mathbf{b}$ & 51 \\
$7^{[c]}$ & -78 to RT & 1.5 & $\mathbf{2 4 ~ b}$ & 48 \\
\hline
\end{tabular}

[a] The ylide was generated in situ by the addition of NaHMDS (1 equiv) at $-50^{\circ} \mathrm{C}$. [b] The ylide was added to the aldehyde at $-78^{\circ} \mathrm{C}$. [c] The aldehyde was added to the ylide at $-78^{\circ} \mathrm{C}$. [d] The purity of the aldehyde was below $70 \%$ (as estimated by using NMR analysis).

The deuterium atoms were either introduced through the reduction of an ester group by using $\mathrm{LiAlD}_{4}$ or through the nucleophilic substitution of a deprotonated alkyne on deuterated paraformaldehyde. The key Wittig olefination reactions between deuterated ylides and EPA-derived aldehydes were optimized to highlight the essential parameters that were necessary for obtaining good reproducibility and robustness of this approach. As such, although this strategy comprised multiple steps, the target deuterated DHA analogues were obtained on a scale of hundreds of milligrams, which was sufficient to allow their use in both in vitro and in vivo studies.

These new deuterated DHA compounds could allow us to better understand the beneficial or deleterious effects of DHAoxidized metabolites and to explain some of the paradoxical studies that have reported no increase in the susceptibility of DHA-enriched cells under specific oxidative conditions. ${ }^{[34]}$ Moreover, these compounds could act as a starting point for the development of new therapeutic DHA analogues that are less prone to deleterious non-enzymatic oxidation, whilst preserving their enzymatic metabolization into neuroprotectins, for example. Finally, studies on the effect of the incorporation of bis-allylic deuterium in both of the synthesized deuterated DHA analogues, and on their inhibition of lipid peroxidation in retinal cells lines, are underway.

\section{Experimental Section}

\section{General Methods}

All of the reactions that required anhydrous conditions were performed in oven-dried glassware with magnetic stirring under a nitrogen atmosphere unless otherwise noted. Solvents, anhydrous solvents, and reagents were used as received unless otherwise noted. The reactions were monitored by using TLC on plates that were precoated with silica gel 60 (Merck). The reaction components were visualized by using a $254 \mathrm{~nm}$ UV lamp, staining with acidic $p$-anisaldehyde solution followed by gentle heating, or staining with $\mathrm{KMNO}_{4}$ solution in EtOH. Organic layers were dried with $\mathrm{MgSO}_{4}$ unless otherwise stated. Column chromatography were performed on silica gel $40-63 \mu \mathrm{m} .{ }^{1} \mathrm{H}$ and ${ }^{13} \mathrm{C}$ NMR spectra were recorded at $500 \mathrm{MHz}$ in $\mathrm{CDCl}_{3}$ (internal reference at $\delta=7.26 \mathrm{ppm}$ for ${ }^{1} \mathrm{H}$ NMR and $\delta=77.16 \mathrm{ppm}$ for ${ }^{13} \mathrm{C}$ NMR) unless otherwise noted. The NMR spectra were assigned with the help of 2D NMR analysis
(' $\mathrm{H}-{ }^{1} \mathrm{H}$ COSY, HSQC, and $\mathrm{HMBC}$ ). The multiplicities are reported as follows: $b r=$ broad, $m=$ multiplet, $s=$ singlet, $d=$ doublet, $t=$ triplet, $q=$ quadruplet, quint = quintuplet, or combinations thereof. MS and HRMS were recorded by using electrospray ionization (ESI) or atmospheric pressure chemical ionization (APCI) techniques with an atmospheric solids analysis probe (ASAP) on Q-TOF mass spectrometers.

It was necessary to consider the high volatilities of compounds 4, 6 , and 7 during the different workups in their syntheses.

Intermediates 3, 4, and $\mathbf{5}$ were synthesized on a gram scale; the Wittig and hydrogenation reactions for the synthesis of compounds 1 and $\mathbf{2}$ were synthesized on a scale of hundreds of milligrams.

\section{Methyl 2-(4-Methoxybenzyloxy)ethanoate (6)}

A solution of 4-methoxybenzyl alcohol $(8.54 \mathrm{~g}, 61.80 \mathrm{mmol})$ in dry $\mathrm{Et}_{2} \mathrm{O}(50 \mathrm{~mL}$ ) was added dropwise to a suspension of sodium hydride $(60 \%$ in mineral oil, $148 \mathrm{mg}, 6.18 \mathrm{mmol})$ in dry $\mathrm{Et}_{2} \mathrm{O}(30 \mathrm{~mL})$ at RT under an inert atmosphere. After $30 \mathrm{~min}$, the mixture was cooled to $0^{\circ} \mathrm{C}$ and trichloroacetonitrile $(9.82 \mathrm{~g}, 68 \mathrm{mmol})$ was added dropwise. After the addition was complete, the reaction mixture was allowed to warm to RT and stirred for a further $4 \mathrm{~h}$. Then, the solvent was removed under reduced pressure to give the crude intermediate $p$-methoxybenzyl trichloroacetimidate (PMBTCA). Methyl glycolate $(3.90 \mathrm{~g}, 43.30 \mathrm{mmol})$ was added to a solution of the intermediate in dry $\mathrm{CH}_{2} \mathrm{Cl}_{2}(210 \mathrm{~mL})$ under an inert atmosphere, the mixture was cooled to $0{ }^{\circ} \mathrm{C}$, and (+)-camphor-10sulfonic acid $(1 \mathrm{~g}, 4.33 \mathrm{mmol})$ was added. After the addition was complete, the reaction mixture was allowed to warm to RT and stirred for a further $1 \mathrm{~d}$. The obtained suspension was filtered through a pad of Celite ${ }^{\circledR}$ and the filtrate was washed with a saturated aqueous solution of $\mathrm{NaHCO}_{3}(100 \mathrm{~mL})$, dried over $\mathrm{Na}_{2} \mathrm{SO}_{4}$, filtered, and the solvents were removed under reduced pressure ( $600 \mathrm{mbar}$ at $40^{\circ} \mathrm{C}$ ). The residue was purified by column chromatography on silica gel ( $n$-pentane/ $\mathrm{Et}_{2} \mathrm{O}, 9: 1$ to $\left.6: 4\right)$ to give the protected alcohol $(8 ; 8.74 \mathrm{~g}, 96 \%$ yield) as a pale-yellow oil.

$R_{\mathrm{f}}=0.44$ (n-pentane/Et $\left.{ }_{2} \mathrm{O}, 7: 3\right) ;{ }^{1} \mathrm{H}$ NMR $\left(500 \mathrm{MHz}, \mathrm{CDCl}_{3}\right): \delta=7.30-$ $7.28\left(\mathrm{~m}, 2 \mathrm{H} ; \mathrm{CH}_{\mathrm{Ar}}\right), 6.89-6.87\left(\mathrm{~m}, 2 \mathrm{H} ; \mathrm{CH}_{\mathrm{Ar}}\right), 4.56\left(\mathrm{~s}, 2 \mathrm{H} ; \mathrm{CH}_{2(\mathrm{PMB})}\right)$, $4.07\left(\mathrm{~s}, 2 \mathrm{H} ; \mathrm{CH}_{2}\right), 3.80\left(\mathrm{~s}, 3 \mathrm{H} ; \mathrm{CH}_{3(\mathrm{PMB})}\right), 3.75 \mathrm{ppm}\left(\mathrm{s}, 3 \mathrm{H} ; \mathrm{CH}_{3}\right)$; ${ }^{13} \mathrm{C} \mathrm{NMR}\left(126 \mathrm{MHz}, \mathrm{CDCl}_{3}\right): \delta=171.0,159.6,129.9(2 \mathrm{C}), 129.2,114.0$ (2C), 73.1, 66.9, 55.4, $52.0 \mathrm{ppm}$.

\section{1,1-Dideuterio-2-(4-methoxybenzyloxy) Ethanol (7)}

A solution of ester $6(671 \mathrm{mg}, 3.19 \mathrm{mmol})$ in dry $\mathrm{Et}_{2} \mathrm{O}(9 \mathrm{~mL})$ was added dropwise to a suspension of lithium aluminum deuteride $\left(\mathrm{LiAlD}_{4} ; 134 \mathrm{mg}, 3.19 \mathrm{mmol}\right)$ in dry $\mathrm{Et}_{2} \mathrm{O}(9 \mathrm{~mL})$ at $0^{\circ} \mathrm{C}$ under an inert atmosphere. The mixture was stirred for $2 \mathrm{~h}$ at $0^{\circ} \mathrm{C}$ and then carefully quenched with an aqueous solution of Rochelle salt $(1 \mathrm{M}$, $5 \mathrm{~mL}$ ). The layers were separated and the aqueous layer was extracted with $\mathrm{Et}_{2} \mathrm{O}(3 \times 10 \mathrm{~mL})$. The combined organic layers were dried over $\mathrm{Na}_{2} \mathrm{SO}_{4}$, filtered, and the solvents were removed under reduced pressure $\left(600 \mathrm{mbar}\right.$ at $\left.40^{\circ} \mathrm{C}\right)$. The residue was purified by column chromatography on silica gel ( $n$-pentane/ $\left.\mathrm{Et}_{2} \mathrm{O}, 1: 1\right)$ to give deuterated alcohol 7 (535 mg, $91 \%$ yield) as a colorless oil.

$R_{\mathrm{f}}=0.25$ (n-pentane/EtOAc, 1:1); ${ }^{1} \mathrm{H} \mathrm{NMR}\left(500 \mathrm{MHz}, \mathrm{CDCl}_{3}\right): \delta=$ 7.28-7.26 (m, $\left.2 \mathrm{H} ; \mathrm{CH}_{\mathrm{Ar}}\right), 6.90-6.88\left(\mathrm{~m}, 2 \mathrm{H} ; \mathrm{CH}_{\mathrm{Ar}}\right), 4.48(\mathrm{~s}, 2 \mathrm{H}$; $\left.\mathrm{CH}_{2(\mathrm{PMB})}\right), 3.80 \mathrm{ppm}\left(\mathrm{s}, 3 \mathrm{H} ; \mathrm{CH}_{3(\mathrm{PMB})}\right), 3.55 \mathrm{ppm}\left(\mathrm{s}, 2 \mathrm{H} ; \mathrm{CH}_{2}\right) ;{ }^{13} \mathrm{C}$ NMR $\left(126 \mathrm{MHz}, \mathrm{CDCl}_{3}\right): \delta=159.4,130.2,129.6$ (2C), $114.0(2 \mathrm{C}), 73.1,71.1$, 61.4 (quint, ${ }^{1} J(C, D)=21.7 \mathrm{~Hz}$ ), 55.4 ppm. 


\section{1,1-Dideuterio-2-(4-methoxybenzyloxy)ethyl 4-Methylbenzene- sulfonate (8)}

Triethylamine $(2.2 \mathrm{~mL}, 16.30 \mathrm{mmol})$ and tosyl chloride $(3.10 \mathrm{~g}$, $16.30 \mathrm{mmol})$ were added to a solution of alcohol $7(1 \mathrm{~g}$, $5.43 \mathrm{mmol})$ in $\mathrm{CH}_{2} \mathrm{Cl}_{2}(40 \mathrm{~mL})$ at $\mathrm{RT}$ under an inert atmosphere. The mixture was stirred for $20 \mathrm{~h}$ and then quenched with $\mathrm{CH}_{2} \mathrm{Cl}_{2}$ $(120 \mathrm{~mL})$ and a saturated aqueous solution of $\mathrm{NaHCO}_{3}(20 \mathrm{~mL})$. The layers were separated and the aqueous layer was extracted with $\mathrm{CH}_{2} \mathrm{Cl}_{2}(80 \mathrm{~mL})$. The combined organic layers were dried over $\mathrm{Na}_{2} \mathrm{SO}_{4}$, filtered, and the solvents were removed under reduced pressure. The residue was purified by column chromatography on silica gel ( $n$-pentane/ $\mathrm{Et}_{2} \mathrm{O}, 7: 3$ to 1:1) to give activated alcohol 8 ( $1.77 \mathrm{~g}, 97 \%$ yield) as a white solid.

$R_{\mathrm{f}}=0.40$ ( $n$-pentane/EtOAc, 7:3); ${ }^{1} \mathrm{H} \mathrm{NMR}\left(500 \mathrm{MHz}, \mathrm{CDCl}_{3}\right): \delta=$ 7.80-7.77 (m, 2H; $\left.\mathrm{CH}_{\text {Ar }(\mathrm{Ts})}\right), 7.32-7.30\left(\mathrm{~m}, 2 \mathrm{H} ; \mathrm{CH}_{\text {Ar(Ts }}\right), 7.20-7.17(\mathrm{~m}$, $\left.2 \mathrm{H} ; \mathrm{CH}_{\text {Ar(PMB })}\right), 6.87-6.84\left(\mathrm{~m}, 2 \mathrm{H} ; \mathrm{CH}_{\text {Ar(PMB })}\right), 4.41\left(\mathrm{~s}, 2 \mathrm{H} ; \mathrm{CH}_{2(\mathrm{PMB})}\right), 3.80$ $\left(\mathrm{s}, 3 \mathrm{H} ; \mathrm{CH}_{3(\mathrm{PMB})}\right), 3.62\left(\mathrm{~s}, 2 \mathrm{H} ; \mathrm{CH}_{2}\right), 2.43 \mathrm{ppm}\left(\mathrm{s}, 3 \mathrm{H} ; \mathrm{CH}_{3(\mathrm{Ts})}\right) ;{ }^{13} \mathrm{C} \mathrm{NMR}$ $\left(126 \mathrm{MHz}, \mathrm{CDCl}_{3}\right): \delta=159.4,144.9,133.1,129.9$ (2C), 129.7, 129.5 (2C), $128.1(2 \mathrm{C}), 113.9(2 \mathrm{C}), 73.0,68.8$ (quint, ${ }^{1} J(C, D)=22.7 \mathrm{~Hz}$ ), 67.1, 55.4, $21.8 \mathrm{ppm}$; HRMS (ASAP+): $\mathrm{m} / z$ calcd for $\mathrm{C}_{17} \mathrm{H}_{18} \mathrm{D}_{2} \mathrm{O}_{5} \mathrm{~S}$ : $338.1157[M]^{+\bullet} ;$ found: 338.1157 .

\section{1-((But-3-yn-1,1-dideuterio-1-yloxy)methyl)-4-methoxybenzene} (4)

A solution of activated alcohol 8 (664 mg, $1.96 \mathrm{mmol})$ in dry DMSO $(4 \mathrm{~mL})$ was added dropwise to a suspension of LiCCH.EDA $(90 \%$, $300 \mathrm{mg}, 2.95 \mathrm{mmol})$ in dry DMSO $(2 \mathrm{~mL})$ at $10^{\circ} \mathrm{C}$ under an inert atmosphere. The mixture was stirred for $15 \mathrm{~min}$ at $10^{\circ} \mathrm{C}$ and then allowed to warm to RT. Then, the mixture was stirred for a further $4 \mathrm{~h}$ and carefully quenched with $\mathrm{CH}_{2} \mathrm{Cl}_{2}(20 \mathrm{~mL})$, water $(10 \mathrm{~mL})$, and brine $(10 \mathrm{~mL})$. The layers were separated and the aqueous layer was extracted with $\mathrm{CH}_{2} \mathrm{Cl}_{2}(4 \times 10 \mathrm{~mL})$. The combined organic layers were dried over $\mathrm{Na}_{2} \mathrm{SO}_{4}$, filtered, and the solvents were removed under reduced pressure $\left(500 \mathrm{mbar}\right.$ at $\left.40^{\circ} \mathrm{C}\right)$. The residue was purified by column chromatography on silica gel ( $n$-pentane/Et ${ }_{2} \mathrm{O}$, $95: 5)$ to give deuterated alkyne 4 ( $290 \mathrm{mg}, 77 \%$ yield) as a paleyellow oil.

$R_{\mathrm{f}}=0.30$ (n-pentane/Et $\left.\mathrm{E}_{2} \mathrm{O}, 9: 1\right) ;{ }^{1} \mathrm{H}$ NMR $\left(500 \mathrm{MHz}, \mathrm{CDCl}_{3}\right): \delta=7.28-$ $7.26\left(\mathrm{~m}, 2 \mathrm{H} ; \mathrm{CH}_{\mathrm{Ar}}\right), 6.89-6.87\left(\mathrm{~m}, 2 \mathrm{H} ; \mathrm{CH}_{\mathrm{Ar}}\right), 4.49\left(\mathrm{~s}, 2 \mathrm{H} ; \mathrm{CH}_{2(\mathrm{PMB})}\right)$, $3.80\left(\mathrm{~s}, 3 \mathrm{H} ; \mathrm{CH}_{3(\mathrm{PMB})}\right), 3.56\left(\mathrm{~s}, 2 \mathrm{H} ; \mathrm{CH}_{2}\right), 1.99 \mathrm{ppm}(\mathrm{s}, 1 \mathrm{H} ; \mathrm{CH})$; ${ }^{13} \mathrm{C} \mathrm{NMR}\left(126 \mathrm{MHz}, \mathrm{CDCl}_{3}\right): \delta=159.4,130.2,129.5$ (2C), 113.9 (2C), 81.4, 72.8, 69.4, 67.8, 55.4, 19.4 ppm (quint, ${ }^{1} J(C, D)=20.3 \mathrm{~Hz}$ ); HRMS (ASAP+): $\mathrm{m} / \mathrm{z}$ calcd for $\mathrm{C}_{12} \mathrm{H}_{12} \mathrm{D}_{2} \mathrm{O}_{2}: 192.1119\left[\mathrm{M}^{+*}\right.$; found: 192.1118.

\section{2-(Pent-4-yn-1-yloxy)tetrahydro-2H-pyran (9)}

A solution of 2,4-dihydropyran (DHP; $5.78 \mathrm{~g}, 68.80 \mathrm{mmol}$ ) in $\mathrm{CH}_{2} \mathrm{Cl}_{2}$ $(10 \mathrm{~mL})$ was added dropwise to a solution of pent-4-yn-1-ol $(4.82 \mathrm{~g}, 57.30 \mathrm{mmol})$ and $p$-toluenesulfonic acid (PTSA) monohydrate $(272 \mathrm{mg}, 1.43 \mathrm{mmol})$ in $\mathrm{CH}_{2} \mathrm{Cl}_{2}(60 \mathrm{~mL})$ at $\mathrm{RT}$ under an inert atmosphere. The reaction was stirred for $20 \mathrm{~h}$ and then quenched with a saturated aqueous solution of $\mathrm{NaHCO}_{3}(50 \mathrm{~mL})$. The mixture was stirred for a further $15 \mathrm{~min}$ and then the layers were separated. The aqueous layer was extracted with $\mathrm{Et}_{2} \mathrm{O}(50 \mathrm{~mL})$. The combined organic layers were washed with a saturated aqueous solution of $\mathrm{NaHCO}_{3}(2 \times 50 \mathrm{~mL})$ and brine $(2 \times 50 \mathrm{~mL})$, dried over $\mathrm{Na}_{2} \mathrm{SO}_{4}$, filtered, and the solvents were removed under reduced pressure $\left(600 \mathrm{mbar}\right.$ at $\left.40^{\circ} \mathrm{C}\right)$. The residue was purified by column chromatography on silica gel ( $n$-pentane/ $\left.\mathrm{Et}_{2} \mathrm{O}, 95: 5\right)$ to give protected alcohol 9 ( $8.77 \mathrm{~g}, 91 \%$ yield) as a colorless oil.
$R_{\mathrm{f}}=0.22$ (n-pentane/Et $\left.{ }_{2} \mathrm{O}, 95: 5\right) ;{ }^{1} \mathrm{H}$ NMR $\left(500 \mathrm{MHz}, \mathrm{CDCl}_{3}\right): \delta=4.58$ $\left(\mathrm{dd},{ }^{3} \mathrm{~J}(\mathrm{H}, \mathrm{H})=4.1,3.1 \mathrm{~Hz}, 1 \mathrm{H} ; \mathrm{CH}_{(\mathrm{THP})}\right), 3.87-3.79\left(\mathrm{~m}, 2 \mathrm{H} ; \mathrm{CH}_{2(\mathrm{a})}-\mathrm{O}_{(\mathrm{THP})}\right.$ and $\left.\mathrm{CH}_{2(\mathrm{a})}-\mathrm{O}\right), 3.51-3.44\left(\mathrm{~m}, 2 \mathrm{H}_{;} \mathrm{CH}_{2(\mathrm{~b})}-\mathrm{O}_{(\mathrm{THP})}\right.$ and $\left.\mathrm{CH}_{2(\mathrm{~b})}-\mathrm{O}\right), 2.29$ (tdd, $\left.{ }^{3} \mathrm{~J}(\mathrm{H}, \mathrm{H})=6.6,2.6,1.6 \mathrm{~Hz}, 2 \mathrm{H} ; \mathrm{CH}_{2}-\mathrm{C} \equiv \mathrm{C}\right), 1.93\left(\mathrm{t}^{3}{ }^{3} \mathrm{~J}(\mathrm{H}, \mathrm{H})=\right.$ $2.6 \mathrm{~Hz}, 1 \mathrm{H} ; \mathrm{C} \equiv \mathrm{CH}), 1.82-1.76\left(\mathrm{~m}, 3 \mathrm{H} ; \mathrm{CH}_{2(\mathrm{a})}-\mathrm{CH}_{(\mathrm{THP})}\right.$ and $\mathrm{CH}_{2}-\mathrm{CH}_{2}-$ $\left.\mathrm{CH}_{2}\right), 1.71-1.66\left(\mathrm{~m}, 1 \mathrm{H} ; \mathrm{CH}_{2(\mathrm{~b})}-\mathrm{CH}_{(\mathrm{THP})}\right), 1.58-1.48 \mathrm{ppm}(\mathrm{m}, 4 \mathrm{H}$; $\left.\mathrm{CH}_{2(\mathrm{THP})}\right) ;{ }^{13} \mathrm{C}$ NMR $\left(126 \mathrm{MHz}, \mathrm{CDCl}_{3}\right): \delta=98.9,84.1,68.5,65.8,62.3$, $30.7,28.8,25.6,19.6,15.4 \mathrm{ppm}$.

\section{1,1-Dideuterio-6-(tetrahydro-2H-pyran-2-yloxy)hex-2-yn-1-ol (10)}

A commercial solution of ethyl magnesium bromide $(0.90 \mathrm{M}$ in THF, $13.2 \mathrm{~mL})$ was added dropwise to a solution of alkyne $9(1 \mathrm{~g}$, $5.94 \mathrm{mmol})$ in dry THF (6 mL) at RT under an inert atmosphere and the mixture was stirred at reflux for $1.5 \mathrm{~h}$. Then, the mixture was cooled to $0^{\circ} \mathrm{C}$, deuterated paraformaldehyde $(286 \mathrm{mg}, 8.90 \mathrm{mmol})$ was added, and the mixture was stirred at reflux for a further $15 \mathrm{~h}$. The reaction was cooled to $0{ }^{\circ} \mathrm{C}$ and carefully quenched with $\mathrm{Et}_{2} \mathrm{O}$ $(20 \mathrm{~mL})$ and a saturated aqueous solution of $\mathrm{NaHCO}_{3}(10 \mathrm{~mL})$. The obtained suspension was filtered through a pad of Celite ${ }^{\circledR}$ and the solid was washed with $\mathrm{Et}_{2} \mathrm{O}(2 \times 20 \mathrm{~mL})$. The layers were separated and the aqueous layer was extracted with $\mathrm{Et}_{2} \mathrm{O}(3 \times 20 \mathrm{~mL})$. The combined organic layers were washed with brine $(2 \times 10 \mathrm{~mL})$, dried over $\mathrm{Na}_{2} \mathrm{SO}_{4}$, filtered, and the solvents were removed under reduced pressure. The residue was purified by column chromatography on silica gel ( $n$-pentane/ $\mathrm{Et}_{2} \mathrm{O}, 7: 3$ to $5: 5$ ) to give deuterated alcohol 10 (1.02 g, 86\% yield) as a colorless oil.

$R_{\mathrm{f}}=0.16$ (n-pentane/ $\left.\mathrm{Et}_{2} \mathrm{O}, 7: 3\right) ;{ }^{1} \mathrm{H}$ NMR $\left(500 \mathrm{MHz}, \mathrm{CDCl}_{3}\right): \delta=4.57$ $\left(\mathrm{dd},{ }^{3} \mathrm{~J}(\mathrm{H}, \mathrm{H})=4.2,3.0 \mathrm{~Hz}, 1 \mathrm{H} ; \mathrm{CH}_{(\mathrm{THP})}\right), 3.86-3.77\left(\mathrm{~m}, 2 \mathrm{H} ; \mathrm{CH}_{2(\mathrm{a})}-\mathrm{O}_{(\mathrm{THP})}\right.$ and $\left.\mathrm{CH}_{2(\mathrm{a})}-\mathrm{O}\right), 3.51-3.43\left(\mathrm{~m}, 2 \mathrm{H} ; \mathrm{CH}_{2(\mathrm{~b})}-\mathrm{O}_{(\mathrm{THP})}\right.$ and $\left.\mathrm{CH}_{2(\mathrm{~b})}-\mathrm{O}\right), 2.31(\mathrm{t}$, $\left.{ }^{3} \mathrm{~J}(\mathrm{H}, \mathrm{H})=7.1 \mathrm{~Hz}, 2 \mathrm{H} ; \mathrm{CH}_{2}-\mathrm{C} \equiv \mathrm{C}\right), 1.82-1.74\left(\mathrm{~m}, 3 \mathrm{H} ; \mathrm{CH}_{2(\mathrm{a})}-\mathrm{CH}_{(\mathrm{THP})}\right.$ and $\left.\mathrm{CH}_{2}-\mathrm{CH}_{2}-\mathrm{CH}_{2}\right), 1.71-1.66\left(\mathrm{~m}, 1 \mathrm{H} ; \mathrm{CH}_{2(\mathrm{~b})}-\mathrm{CH}_{(\mathrm{THP})}\right), 1.58-1.47 \mathrm{ppm}(\mathrm{m}$, $\left.4 \mathrm{H}_{;} \mathrm{CH}_{2(\mathrm{THP}}\right) ;{ }^{3} \mathrm{C} \mathrm{NMR}\left(126 \mathrm{MHz}, \mathrm{CDCl}_{3}\right): \delta=98.9,85.5,78.9,66.0$, 62.3, 55.7 (quint, ${ }^{1} J(C, D)=22.3 \mathrm{~Hz}$ ), 30.7, 28.8, 25.5, 19.5, 15.7 ppm.

\section{2-(6-Bromo-6,6-dideuteriohex-4-yn-1-yloxy)tetrahydro-2H- pyran (11)}

A solution of triphenylphoshine $(13.80 \mathrm{~g}, 52.60 \mathrm{mmol})$ in $\mathrm{CH}_{2} \mathrm{Cl}_{2}$ $(50 \mathrm{~mL})$ was added dropwise under an inert atmosphere to a solution of tetrabromomethane $(8.72 \mathrm{~g}, 26.30 \mathrm{mmol})$ in $\mathrm{CH}_{2} \mathrm{Cl}_{2}(50 \mathrm{~mL})$ at $-40^{\circ} \mathrm{C}$. Then, solutions of deuterated alcohol $10(5.26 \mathrm{~g}$, $26.30 \mathrm{mmol})$ and imidazole $(3.58 \mathrm{~g}, 52.60 \mathrm{mmol})$ in $\mathrm{CH}_{2} \mathrm{Cl}_{2}(50 \mathrm{~mL}$ each) were added dropwise to the mixture at $-40^{\circ} \mathrm{C}$. The reaction was stirred at $-40^{\circ} \mathrm{C}$ for $2 \mathrm{~h}$ and then quenched with a saturated aqueous solution of $\mathrm{NaHCO}_{3}(25 \mathrm{~mL})$ and an aqueous solution of $\mathrm{Na}_{2} \mathrm{~S}_{2} \mathrm{O}_{3}(10 \%, 25 \mathrm{~mL})$. The layers were separated and the aqueous layer was extracted with $\mathrm{CH}_{2} \mathrm{Cl}_{2}(2 \times 50 \mathrm{~mL})$. The combined organic layers were washed with water $(2 \times 100 \mathrm{~mL})$, dried over $\mathrm{Na}_{2} \mathrm{SO}_{4}$, filtered, and the solvents were removed under reduced pressure. The residue was triturated with $\mathrm{Et}_{2} \mathrm{O}(50 \mathrm{~mL})$ and the suspension was filtered through a pad of Celite ${ }^{\circledR}$ to remove most of the white solid (triphenylphosphine oxide), which was washed with $\mathrm{Et}_{2} \mathrm{O}(3 \times$ $50 \mathrm{~mL}$ ). The filtrate was concentrated under reduced pressure and the residue was purified by column chromatography on silica gel ( $n$-pentane/ $\mathrm{Et}_{2} \mathrm{O}, 9: 1$ to $7: 3$ ) to give deuterated bromide derivative $11(6.92 \mathrm{~g}, 60 \%$ yield) as a colorless oil.

$R_{\mathrm{f}}=0.39$ ( $n$-pentane/EtOAc, 9:1); ${ }^{1} \mathrm{H}$ NMR $\left(500 \mathrm{MHz}, \mathrm{CDCl}_{3}\right): \delta=4.59$ $\left(\mathrm{m}, 1 \mathrm{H} ; \mathrm{CH}_{(\mathrm{THP})}\right), 3.88-3.77\left(\mathrm{~m}, 2 \mathrm{H} ; \mathrm{CH}_{2}-\mathrm{O}_{(\mathrm{THP})}\right.$ and $\left.\mathrm{CH}_{2}-\mathrm{O}\right), 3.53-$ $3.43\left(\mathrm{~m}, 2 \mathrm{H} ; \mathrm{CH}_{2(\mathrm{~b})}-\mathrm{O}_{(\mathrm{THP})}\right.$ and $\left.\mathrm{CH}_{2(\mathrm{~b})}-\mathrm{O}\right), 2.37\left(\mathrm{t},{ }^{3} \mathrm{~J}(\mathrm{H}, \mathrm{H})=7.1 \mathrm{~Hz}\right.$ $\left.2 \mathrm{H} ; \mathrm{CH}_{2}-\mathrm{C} \equiv \mathrm{C}\right), 1.84-1.77\left(\mathrm{~m}, 3 \mathrm{H} ; \mathrm{CH}_{2(\mathrm{a})}-\mathrm{CH}_{(\mathrm{THP})}\right.$ and $\left.\mathrm{CH}_{2}-\mathrm{CH}_{2}-\mathrm{CH}_{2}\right)$, 1.73-1.70 (m, $\left.1 \mathrm{H} ; \mathrm{CH}_{2(\mathrm{~b})}-\mathrm{CH}_{(\mathrm{THP})}\right), 1.60-1.50 \mathrm{ppm}\left(\mathrm{m}, 4 \mathrm{H} ; \mathrm{CH}_{2(\mathrm{THP})}\right)$; 
${ }^{13} \mathrm{C}$ NMR $\left(126 \mathrm{MHz}, \mathrm{CDCl}_{3}\right): \delta=98.9,87.6,75.5,65.9,62.3,30.7,28.6$, $25.6,19.6,16.0,15.5 \mathrm{ppm}$ (quint, ${ }^{1} J(\mathrm{C}, \mathrm{D})=24.3 \mathrm{~Hz}$ ); HRMS (ASAP+): $\mathrm{m} / \mathrm{z}$ calcd for $\mathrm{C}_{11} \mathrm{H}_{16} \mathrm{D}_{2} \mathrm{BrO}_{2}: 263,0616[\mathrm{M}+\mathrm{H}]^{+}$; found: 263,0616 .

\section{6-Bromo-6,6-dideuteriohex-4-ynoic Acid (12)}

Jones reagent $(2.17 \mathrm{M}, 35 \mathrm{~mL})$ was added dropwise to a solution of deuterated bromide derivative $11(3.95 \mathrm{~g}, 15 \mathrm{mmol})$ in acetone $(40 \mathrm{~mL})$ at $0{ }^{\circ} \mathrm{C}$ and the mixture was stirred at $0{ }^{\circ} \mathrm{C}$ for $30 \mathrm{~min}$. Then, the reaction was quenched with propan-2-ol $(45 \mathrm{~mL})$ and $\mathrm{Et}_{2} \mathrm{O}(200 \mathrm{~mL})$. The suspension is filtered through a pad of Celite ${ }^{\circledR}$ and the green solid was washed with $\mathrm{Et}_{2} \mathrm{O}(4 \times 100 \mathrm{~mL})$. The filtrate was washed with acidified brine $(2 \times 100 \mathrm{~mL}, \mathrm{pH} 1)$, dried over $\mathrm{Na}_{2} \mathrm{SO}_{4}$, filtered, and the solvents were removed under reduced pressure. The obtained residue was purified by column chromatography on silica gel $\left(8: 2\right.$ to $6: 4, n$-pentane/ $\left./ \mathrm{Et}_{2} \mathrm{O}\right)$ to give acid 12 $(2.51 \mathrm{~g}, 87 \%$ yield) as a white solid.

$R_{\mathrm{f}}=0.26$ ( $n$-pentane/EtOAc, 1:1); ${ }^{1} \mathrm{H} \mathrm{NMR}\left(500 \mathrm{MHz}, \mathrm{CDCl}_{3}\right): \delta=$ 2.62-2.55 ppm (m, 4H; $\left.\mathrm{CH}_{2}\right) ;{ }^{13} \mathrm{C}$ NMR $\left(126 \mathrm{MHz}, \mathrm{CDCl}_{3}\right): \delta=178.2$, 85.5, 76.3, 33.1, $14.7 \mathrm{ppm}$ (the $\mathrm{CD}_{2}$ signal was not visible); HRMS (ASAP+): $\mathrm{m} / \mathrm{z}$ calcd for $\mathrm{C}_{6} \mathrm{H}_{6} \mathrm{D}_{2} \mathrm{BrO}_{2}: 192,9833[\mathrm{M}+\mathrm{H}]^{+}$; found: 192,9836

\section{Ethyl 6-Bromo-6,6-dideuteriohex-4-ynoate (5)}

Concentrated $\mathrm{H}_{2} \mathrm{SO}_{4}(250 \mu \mathrm{L})$ was added to a solution of acid 12 $(1.93 \mathrm{~g}, 9.48 \mathrm{mmol})$ in $\mathrm{EtOH}(80 \mathrm{~mL})$ and the mixture was stirred at reflux for $1 \mathrm{~d}$. The reaction was quenched with a saturated aqueous solution of $\mathrm{NaHCO}_{3}(20 \mathrm{~mL})$ and the aqueous layer was extracted with $n$-pentane/ $\mathrm{Et}_{2} \mathrm{O}(1: 1,4 \times 100 \mathrm{~mL})$. The combined organic layers were washed with brine $(100 \mathrm{~mL})$, dried over $\mathrm{Na}_{2} \mathrm{SO}_{4}$, filtered, and the solvents were removed under reduced pressure. The residue was purified by column chromatography on silica gel ( $n$-pentane/ $\left.\mathrm{Et}_{2} \mathrm{O}, 95: 5\right)$ to give deuterated ester $\mathbf{5}(2.07 \mathrm{~g}, 90 \%$ yield) as a pale-yellow oil.

$R_{\mathrm{f}}=0.47$ (n-pentane/EtOAc, 9:1); ${ }^{1} \mathrm{H}$ NMR $\left(500 \mathrm{MHz}, \mathrm{CDCl}_{3}\right): \delta=4.14$ (q, $\left.4 \mathrm{H} ;{ }^{3} J(\mathrm{H}, \mathrm{H})=7.1 \mathrm{~Hz}, 2 \mathrm{H} ; \mathrm{CH}_{2 \text { (ester })}\right), 2.56-2.48\left(\mathrm{~m}, 4 \mathrm{H} ; \mathrm{CH}_{2}\right)$, $1.25 \mathrm{ppm}\left(\mathrm{t},{ }^{3} \mathrm{~J}(\mathrm{H}, \mathrm{H})=7.1 \mathrm{~Hz}, 3 \mathrm{H} ; \mathrm{CH}_{3}\right) ;{ }^{13} \mathrm{C}$ NMR $\left(126 \mathrm{MHz}, \mathrm{CDCl}_{3}\right)$ : $\delta=171.8,86.0,76.0,60.8,33.3,15.0,14.3 \mathrm{ppm}$ (the $\mathrm{CD}_{2}$ signal was not visible).

\section{6,6-Dideutero-7-(4-methoxybenzyloxy)hept-4-yn-1-ol (13)}

A solution of $n$ BuLi ( $1.6 \mathrm{M}$ in $n$-hexane, $1.64 \mathrm{~mL}$ ) was slowly added to a solution of alkyne $4(500 \mathrm{mg}, 2.06 \mathrm{mmol})$ in dry THF $(3 \mathrm{~mL})$ at $-78^{\circ} \mathrm{C}$ under an inert atmosphere and the mixture was stirred at $-78^{\circ} \mathrm{C}$ for $30 \mathrm{~min}$. Then, a solution of oxetane $(85 \mu \mathrm{L}, 1.30 \mathrm{mmol})$ in dry THF $(2.50 \mathrm{~mL})$ was slowly added to the mixture, followed by the slow addition of $\mathrm{BF}_{3} \cdot \mathrm{Et}_{2} \mathrm{O}(320 \mu \mathrm{L}, 2.52 \mathrm{mmol})$. The reaction was stirred at $-78^{\circ} \mathrm{C}$ for $30 \mathrm{~min}$ and quenched with EtOAc $(10 \mathrm{~mL})$, a saturated aqueous solution of $\mathrm{NH}_{4} \mathrm{Cl}(5 \mathrm{~mL})$, and brine $(5 \mathrm{~mL})$. The layers were separated and the aqueous layer was extracted with EtOAc $(2 \times 10 \mathrm{~mL})$. The combined organic layers were dried over $\mathrm{Na}_{2} \mathrm{SO}_{4}$, filtered, and the solvents were removed under reduced pressure. The obtained residue was purified by column chromatography on silica gel ( $n$-pentane/ $\mathrm{Et}_{2} \mathrm{O}, 9: 1$ to $\left.5: 5\right)$ to give deuterated alcohol 13 (258 mg, 79\% yield) as a pale-yellow oil.

$R_{\mathrm{f}}=0.49$ ( $n$-pentane/EtOAc, 1:1); ${ }^{1} \mathrm{H} \mathrm{NMR}\left(500 \mathrm{MHz}, \mathrm{CDCl}_{3}\right): \delta=$ 7.28-7.25 (m, 2H; $\left.\mathrm{CH}_{\mathrm{Ar}}\right), 6.89-6.86\left(\mathrm{~m}, 2 \mathrm{H} ; \mathrm{CH}_{\mathrm{Ar}}\right), 4.47(\mathrm{~s}, 2 \mathrm{H}$; $\left.\mathrm{CH}_{2(\mathrm{PMB})}\right), 3.80\left(\mathrm{~s}, 3 \mathrm{H} ; \mathrm{CH}_{3(\mathrm{PMB})}\right), 3.75-3.72\left(\mathrm{~m}, 2 \mathrm{H} ; \mathrm{CH}_{2}-\mathrm{OH}\right), 3.51(\mathrm{~s}$, $\left.2 \mathrm{H} ; \mathrm{CH}_{2}-\mathrm{O}\right), 2.27\left(\mathrm{t},{ }^{3} \mathrm{~J}(\mathrm{H}, \mathrm{H})=6.9 \mathrm{~Hz}, 2 \mathrm{H} ; \mathrm{CH}_{2}-\mathrm{C} \equiv \mathrm{C}\right), 1.75-1.69 \mathrm{ppm}$ $\left(\mathrm{m}, 2 \mathrm{H} ; \mathrm{CH}_{2}-\mathrm{CH}_{2}-\mathrm{CH}_{2}\right) ;{ }^{13} \mathrm{C}$ NMR $\left(126 \mathrm{MHz}, \mathrm{CDCl}_{3}\right): \delta=159.3,130.3$, 129.5 (2C), 113.9 (2C), 80.7, 77.6, 72.7, 68.4, 61.9, 55.4, 31.5, 19.7 (quint, $\left.{ }^{1} J(C, D)=19.9 \mathrm{~Hz}\right), 15.5 \mathrm{ppm}$; HRMS (ASAP+): $\mathrm{m} / \mathrm{z}$ calcd for $\mathrm{C}_{15} \mathrm{H}_{18} \mathrm{D}_{2} \mathrm{O}_{3}: 250,1538[M]^{+*}$; found: 250,1530 .

\section{6,6-Dideutero-7-(4-methoxybenzyloxy)hept-4-ynoic Acid (14)}

Jones reagent $(2.17 \mathrm{M}, 0.28 \mathrm{~mL})$ was added dropwise to a solution of alcohol $13(100 \mathrm{mg}, 0.40 \mathrm{mmol})$ in acetone $(6 \mathrm{~mL})$ at $0^{\circ} \mathrm{C}$. The mixture was stirred at $0^{\circ} \mathrm{C}$ for $1 \mathrm{~h}$. Then, the reaction was quenched with propan-2-ol $(0.50 \mathrm{~mL})$ and the suspension was filtered through a pad of Celite ${ }^{\circledR}$ and the green solid was washed with EtOAc $(15 \mathrm{~mL})$. The filtrate was washed with acidified water $(5 \mathrm{~mL} ; \mathrm{pH} 1)$ and acidified brine $(10 \mathrm{~mL} ; \mathrm{pH} 1)$, dried over $\mathrm{Na}_{2} \mathrm{SO}_{4}$, filtered, and the solvents were removed under reduced pressure. The obtained residue was purified by column chromatography on silica gel (n-pentane/EtOAc, 9:1 to 6:4) to give acid $14(100 \mathrm{mg}$, $94 \%$ yield) as a white solid.

$R_{\mathrm{f}}=0.20$ (n-pentane/EtOAc, 1:1); ${ }^{1} \mathrm{H} \mathrm{NMR}\left(500 \mathrm{MHz}, \mathrm{CDCl}_{3}\right): \delta=$ 7.28-7.25 (m, 2H; $\left.\mathrm{CH}_{\mathrm{Ar}}\right), 6.89-6.86\left(\mathrm{~m}, 2 \mathrm{H} ; \mathrm{CH}_{\mathrm{Ar}}\right), 4.47(\mathrm{~s}, 2 \mathrm{H}$; $\left.\mathrm{CH}_{2(\mathrm{PMB})}\right), 3.80\left(\mathrm{~s}, 3 \mathrm{H} ; \mathrm{CH}_{3(\mathrm{PMB})}\right), 3.51\left(\mathrm{~s}, 2 \mathrm{H} ; \mathrm{CH}_{2}-\mathrm{O}\right), 2.60-2.42 \mathrm{ppm}$ $\left(\mathrm{m}, 4 \mathrm{H} ; \mathrm{CH}_{2}\right) ;{ }^{13} \mathrm{C}$ NMR $\left(126 \mathrm{MHz}, \mathrm{CDCl}_{3}\right): \delta=177.9,159.3,130.3$, 129.5 (2C), 113.9 (2C), 79.1, 78.0, 72.7, 68.3, 55.4, 33.8, 19.7 (quint, $\left.{ }^{1} J(C, D)=19.7 \mathrm{~Hz}\right), 14.6 \mathrm{ppm}$; HRMS (ESI-): $\mathrm{m} / \mathrm{z}$ calcd for $\mathrm{C}_{15} \mathrm{H}_{15} \mathrm{D}_{2} \mathrm{O}_{4}$ : $263.1252[M-H]^{-}$; found: 263.1250 .

\section{Ethyl 6,6-Dideutero-7-hydroxyhept-4-ynoate (15)}

Concentrated $\mathrm{H}_{2} \mathrm{SO}_{4}(350 \mu \mathrm{L})$ was added to a solution of acid 14 $(100 \mathrm{mg}, 0.38 \mathrm{mmol})$ in $\mathrm{EtOH}(7 \mathrm{~mL})$ and the mixture was stirred at $40^{\circ} \mathrm{C}$ for $4 \mathrm{~d}$ under an inert atmosphere. The reaction was quenched with a saturated aqueous solution of $\mathrm{NaHCO}_{3}(10 \mathrm{~mL})$ and water $(10 \mathrm{~mL})$ and the mixture was extracted with $n$-pentane/ $\mathrm{Et}_{2} \mathrm{O}$ 1:1 $(4 \times 10 \mathrm{~mL})$. The combined organic layers were washed with brine $(100 \mathrm{~mL})$, dried over $\mathrm{Na}_{2} \mathrm{SO}_{4}$, filtered, and the solvents were removed under reduced pressure. The residue was purified by column chromatography on silica gel ( $n$-pentane/Et $\mathrm{t}_{2} \mathrm{O}, 7: 3$ to 1:1) to give ester 15 ( $2.07 \mathrm{~g}, 86 \%$ yield) as a pale-yellow oil.

$R_{\mathrm{f}}=0.57$ (n-pentane/EtOAc, $\left.1: 1\right) ;{ }^{1} \mathrm{H}$ NMR $\left(500 \mathrm{MHz}, \mathrm{CDCl}_{3}\right): \delta=4.13$ $\left(\mathrm{q},{ }^{3} \mathrm{~J}(\mathrm{H}, \mathrm{H})=7 \mathrm{~Hz}, 2 \mathrm{H} ; \mathrm{CH}_{2 \text { (ester) }}\right), 3.64\left(\mathrm{~s}, 2 \mathrm{H} ; \mathrm{CH}_{2}-\mathrm{O}\right), 2.50-2.43(\mathrm{~m}$, $\left.4 \mathrm{H}_{;} \mathrm{CH}_{2}\right), 1.24 \mathrm{ppm}\left(\mathrm{t},{ }^{3} \mathrm{~J}(\mathrm{H}, \mathrm{H})=7.5 \mathrm{~Hz}, 3 \mathrm{H}_{;} \mathrm{CH}_{3(\text { ester })}\right) ;{ }^{13} \mathrm{C} \mathrm{NMR}$ $\left(126 \mathrm{MHz}, \mathrm{CDCl}_{3}\right): \delta=172.4,80.6,77.7,61.2,60.8,34.0,22.6$ (quint, $1 J(C, D)=19.9 \mathrm{~Hz}), 14.9,14.3 \mathrm{ppm}$; HRMS (ASAP+): $\mathrm{m} / \mathrm{z}$ calcd for $\mathrm{C}_{9} \mathrm{H}_{13} \mathrm{D}_{2} \mathrm{O}_{3}: 173.1147[\mathrm{M}+\mathrm{H}]^{+}$; found: 173.1147 .

\section{(4Z)-Ethyl 6,6-Dideutero-7-hydroxyhept-4-enoate (16)}

A solution of $\mathrm{NaBH}_{4}$ in $\mathrm{EtOH}(0.50 \mathrm{M}, 0.56 \mathrm{~mL})$ was added dropwise to a solution of $\mathrm{Ni}(\mathrm{OAc})_{2} \cdot 4 \mathrm{H}_{2} \mathrm{O}(139 \mathrm{mg}, 0.56 \mathrm{mmol})$ in $\mathrm{EtOH}$ $(25 \mathrm{~mL})$ at $0^{\circ} \mathrm{C}$ under a hydrogen atmosphere. The mixture was stirred at $0^{\circ} \mathrm{C}$ for $15 \mathrm{~min}$ and ethylenediamine $(0.22 \mathrm{~mL}$, $3.35 \mathrm{mmol}$ ) was added. After a further $15 \mathrm{~min}$ at $0{ }^{\circ} \mathrm{C}$, a solution of deuterated alkyne 15 (384 mg, $2.23 \mathrm{mmol})$ in $\mathrm{EtOH}(15 \mathrm{~mL})$ was added. Before and after each addition, three cycles of vacuum $/ \mathrm{H}_{2}$ addition were performed. The reaction was stirred for $40 \mathrm{~min}$ at $0{ }^{\circ} \mathrm{C}$ under a hydrogen atmosphere and then quenched with a saturated aqueous solution of $\mathrm{NH}_{4} \mathrm{Cl}(30 \mathrm{~mL})$ and brine $(30 \mathrm{~mL})$. The reaction mixture was extracted with $\mathrm{Et}_{2} \mathrm{O}(3 \times 50 \mathrm{~mL})$ and the combined organic layers were dried over $\mathrm{Na}_{2} \mathrm{SO}_{4}$, filtered, and the solvents were removed under reduced pressure. The residue was purified by column chromatography on silica gel ( $n$-pentane/EtOAc, $6: 4)$ to give alkene 16 (371 mg, 90\% yield) as a pale-yellow oil (with $5 \%$ of the over-reduced byproduct).

$R_{\mathrm{f}}=0.30$ ( $n$-pentane/EtOAc, 7:3); ${ }^{1} \mathrm{H} \mathrm{NMR}\left(500 \mathrm{MHz}, \mathrm{CDCl}_{3}\right): \delta=$ 5.50-5.45 (m, 1 H; CH-CH $)_{2}, 5.41\left(\mathrm{~d},{ }^{3} \mathrm{~J}(\mathrm{H}, \mathrm{H})=11 \mathrm{~Hz}, 1 \mathrm{H} ; \mathrm{CH}-\mathrm{CD}_{2}\right)$, $4.10\left(\mathrm{q},{ }^{3} \mathrm{~J}(\mathrm{H}, \mathrm{H})=7 \mathrm{~Hz}, 2 \mathrm{H} ; \mathrm{CH}_{2 \text { (ester) }}\right), 3.61\left(\mathrm{~s}, 2 \mathrm{H} ; \mathrm{CH}_{2}-\mathrm{O}\right), 2.40-2.33$ 
$\left(\mathrm{m}, 4 \mathrm{H} ; \mathrm{CH}_{2}\right), 1.22 \mathrm{ppm}\left(\mathrm{t},{ }^{3} J(\mathrm{H}, \mathrm{H})=7 \mathrm{~Hz}, 3 \mathrm{H} ; \mathrm{CH}_{3(\text { ester })}\right) ;{ }^{13} \mathrm{C} \mathrm{NMR}$ $\left(126 \mathrm{MHz}, \mathrm{CDCl}_{3}\right): \delta=173.4,130.8,127.1,62.0,60.5,34.1,30.2$ (quint, ${ }^{1} J(C, D)=19.2 \mathrm{~Hz}$ ), 22.8, $14.3 \mathrm{ppm}$.

\section{(4Z)-Ethyl 6,6-Dideutero-7-iodohept-4-enoate (16')}

Imidazole (348 mg, $5.11 \mathrm{mmol}$ ) and triphenylphosphine $(671 \mathrm{mg}$ $2.56 \mathrm{mmol})$ were added to a solution of $\mathrm{I}_{2}(650 \mathrm{mg}, 2.56 \mathrm{mmol})$ in $\mathrm{CH}_{2} \mathrm{Cl}_{2}(14 \mathrm{~mL})$ under an inert atmosphere. The mixture was cooled to $0^{\circ} \mathrm{C}$ and a solution of alcohol $16(371 \mathrm{mg}, 2.13 \mathrm{mmol})$ in $\mathrm{CH}_{2} \mathrm{Cl}_{2}$ $(14 \mathrm{~mL})$ was added. After the addition was complete, the reaction mixture was allowed to warm to RT and stirred for a further $2 \mathrm{~h}$. Then, the reaction was quenched with a saturated aqueous solution of $\mathrm{Na}_{2} \mathrm{~S}_{2} \mathrm{O}_{3}(20 \mathrm{~mL})$, water $(20 \mathrm{~mL})$, and $\mathrm{CH}_{2} \mathrm{Cl}_{2}(15 \mathrm{~mL})$. The layers were separated and the aqueous layer was extracted with $\mathrm{CH}_{2} \mathrm{Cl}_{2}(20 \mathrm{~mL})$. The combined organic layers were dried over $\mathrm{Na}_{2} \mathrm{SO}_{4}$, filtered, and the solvents were removed under reduced pressure. The residue was purified by column chromatography on silica gel $\left(95: 5 n\right.$-pentane/ $\left.\mathrm{Et}_{2} \mathrm{O}\right)$ to give iodide derivative $\mathbf{1 6}^{\prime}$ (538 $\mathrm{mg}, 89 \%$ yield) as a pale-yellow oil.

$R_{\mathrm{f}}=0.48$ ( $n$-pentane/EtOAc, 9:1); ${ }^{1} \mathrm{H} \mathrm{NMR}\left(500 \mathrm{MHz}, \mathrm{CDCl}_{3}\right): \delta=$ 5.53-5.48 $\left(\mathrm{m}, 1 \mathrm{H} ; \mathrm{CH}-\mathrm{CH}_{2}\right), 5.37\left(\mathrm{~d},{ }^{3} \mathrm{~J}(\mathrm{H}, \mathrm{H})=10.5 \mathrm{~Hz}, 1 \mathrm{H} ; \mathrm{CH}-\mathrm{CD}_{2}\right)$,

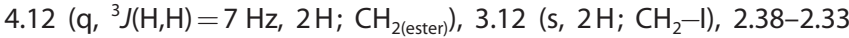
$\left(\mathrm{m}, 4 \mathrm{H} ; \mathrm{CH}_{2}\right), 1.25 \mathrm{ppm}\left(\mathrm{t},{ }^{3} \mathrm{~J}(\mathrm{H}, \mathrm{H})=7 \mathrm{~Hz}, 3 \mathrm{H} ; \mathrm{CH}_{3 \text { (ester })}\right) ;{ }^{13} \mathrm{C} \mathrm{NMR}$ $\left(126 \mathrm{MHz}, \mathrm{CDCl}_{3}\right): \delta=173.1,130.3,129.3,60.4,34.2,30.8$ (quint, $\left.{ }^{1} J(C, D)=19.7 \mathrm{~Hz}\right), 23.1,14.4,5.1 \mathrm{ppm}$; HRMS (ASAP+): $\mathrm{m} / \mathrm{z}$ calcd for $\mathrm{C}_{9} \mathrm{H}_{14} \mathrm{D}_{2} \mathrm{IO}_{2}: 285.0321[\mathrm{M}+\mathrm{H}]^{+}$; found: 285.0317.

\section{(3Z)-(2,2-Dideutero-7-ethoxy-7-oxohept-3-en-1-yl)triphenyl- phosphonium lodide (2a)}

Triphenylphosphine $(595 \mathrm{mg}, 2.27 \mathrm{mmol}$ ) was added to a solution of iodide derivative $16^{\prime}(538 \mathrm{mg}, 1.89 \mathrm{mmol})$ in $\mathrm{MeCN}(15 \mathrm{~mL})$ at RT under an inert atmosphere. The mixture was stirred at reflux for $20 \mathrm{~h}$ and the solvent was removed under reduced pressure. The residue was purified by column chromatography on silica gel $\left(\mathrm{CH}_{2} \mathrm{Cl}_{2} / \mathrm{MeOH}, 98: 2\right.$ to $\left.90: 10\right)$ to give phosphonium salt 2 a (1.02 g, $98 \%$ yield) as a clear wax.

$R_{\mathrm{f}}=0.18\left(\mathrm{CH}_{2} \mathrm{Cl}_{2} / \mathrm{MeOH}, 7: 3\right) ;{ }^{1} \mathrm{H}$ NMR $\left(500 \mathrm{MHz}, \mathrm{CDCl}_{3}\right): \delta=7.83-$ $7.68\left(\mathrm{~m}, 15 \mathrm{H} ; \mathrm{CH}_{\mathrm{Ar}}\right), 5.64\left(\mathrm{~d},{ }^{3} \mathrm{~J}(\mathrm{H}, \mathrm{H})=11 \mathrm{~Hz}, 1 \mathrm{H} ; \mathrm{CH}-\mathrm{CD}_{2}\right), 5.36-$ $5.31\left(\mathrm{~m}, 1 \mathrm{H} ; \mathrm{CH}-\mathrm{CH}_{2}\right), 4.04\left(\mathrm{q},{ }^{3} \mathrm{~J}(\mathrm{H}, \mathrm{H})=7 \mathrm{~Hz}, 2 \mathrm{H} ; \mathrm{CH}_{2 \text { (ester) }}\right), 3.65(\mathrm{~d}$, $\left.{ }^{2} \mathrm{~J}(\mathrm{H}, \mathrm{P})=12 \mathrm{~Hz}, 2 \mathrm{H} ; \mathrm{CH}_{2}-\mathrm{P}\right), 2.27\left(\mathrm{t},{ }^{3} \mathrm{~J}(\mathrm{H}, \mathrm{H})=7 \mathrm{~Hz}, 2 \mathrm{H} ; \mathrm{CH}_{2}\right), 2.13-$ $2.09\left(\mathrm{~m}, 2 \mathrm{H} ; \mathrm{CH}_{2}-\mathrm{CH}\right), 1.19 \mathrm{ppm}\left(\mathrm{t},{ }^{3} \mathrm{~J}(\mathrm{H}, \mathrm{H})=7 \mathrm{~Hz}, 3 \mathrm{H} ; \mathrm{CH}_{3(\text { ester })}\right)$; ${ }^{13} \mathrm{C}$ NMR $\left(126 \mathrm{MHz}, \mathrm{CDCl}_{3}\right): \delta=173.1,135.3\left(\mathrm{~d},{ }^{4} J(\mathrm{C}, \mathrm{P})=3 \mathrm{~Hz}, 3 \mathrm{C}\right)$, $133.8\left(d,{ }^{3} J(C, P)=10.2 \mathrm{~Hz}, 6 C\right), 130.7\left(d,{ }^{2} J(C, P)=12.4 \mathrm{~Hz}, 6 C\right), 130.5$ $\left(d,{ }^{4} J(C, P)=1.4 \mathrm{~Hz}\right), 127.3\left(\mathrm{~d},{ }^{3} J(C, P)=15.8 \mathrm{~Hz}\right), 118.0\left(\mathrm{~d},{ }^{1} J(C, P)=\right.$ $85.9 \mathrm{~Hz}, 3 \mathrm{C}), 60.5,33.5,23.0\left(\mathrm{~d},{ }^{1} J(C, P)=48.5 \mathrm{~Hz}\right), 22.7,20.1-19.5$ (m), $14.3 \mathrm{ppm} ;{ }^{31} \mathrm{P}$ NMR $\left(120 \mathrm{MHz}, \mathrm{CDCl}_{3}\right): \delta=23.8 \mathrm{ppm}$; HRMS $(\mathrm{ESI}+): \mathrm{m} / \mathrm{z}$ calcd for $\mathrm{C}_{27} \mathrm{H}_{28} \mathrm{D}_{2} \mathrm{O}_{2} \mathrm{P}: 419.2109[\mathrm{M}-\mathrm{I}]^{+}$; found: 419.2110 .

\section{Ethyl 6,6,9,9-Tetradeutero-10-(4-methoxybenzyloxy)deca-4,7- diynoate (17)}

A solution of terminal alkyne $4(1.63 \mathrm{~g}, 8.50 \mathrm{mmol})$ in DMF $(40 \mathrm{~mL})$ was added to a solution of $\mathrm{Cul}(3.40 \mathrm{~g}, 17.80 \mathrm{mmol}), \mathrm{Nal}(2.67 \mathrm{~g}$, $17.80 \mathrm{mmol})$, and $\mathrm{K}_{2} \mathrm{CO}_{3}(3.52 \mathrm{~g}, 25.50 \mathrm{mmol})$ in DMF $(25 \mathrm{~mL})$ at $20^{\circ} \mathrm{C}$. A solution of bromide derivative $5(1.88 \mathrm{~g}, 8.50 \mathrm{mmol})$ in DMF $\left(30 \mathrm{~mL}\right.$ ) was immediately added to the mixture at $20^{\circ} \mathrm{C}$ and the mixture was stirred at $20^{\circ} \mathrm{C}$ for $15 \mathrm{~h}$ and then quenched with a saturated aqueous solution of $\mathrm{NH}_{4} \mathrm{Cl}(100 \mathrm{~mL})$ and brine $(100 \mathrm{~mL})$. The aqueous layer was extracted with EtOAc $(3 \times 200 \mathrm{~mL})$. The combined organic layers were washed with brine $(2 \times 50 \mathrm{~mL})$ and water $(50 \mathrm{~mL})$, dried over $\mathrm{Na}_{2} \mathrm{SO}_{4}$, filtered, and the solvents were removed under reduced pressure. The residue was purified by column chromatography on silica gel ( $n$-pentane/Et $\left.{ }_{2} \mathrm{O}, 9: 1\right)$ to give the coupling product $(17 ; 2.12 \mathrm{~g}, 75 \%$ yield) as a pale-yellow oil.

$R_{\mathrm{f}}=0.20$ ( $n$-pentane/EtOAc, 9:1); ${ }^{1} \mathrm{H} \mathrm{NMR}\left(500 \mathrm{MHz}, \mathrm{CDCl}_{3}\right): \delta=$ 7.27-7.24 $\left(\mathrm{m}, 2 \mathrm{H} ; \mathrm{CH}_{\mathrm{Ar}}\right), 6.88-6.86\left(\mathrm{~m}, 2 \mathrm{H} ; \mathrm{CH}_{\mathrm{Ar}}\right), 4.47(\mathrm{~s}, 2 \mathrm{H}$; $\left.\mathrm{CH}_{2(\mathrm{PMB})}\right), 4.14\left(\mathrm{q},{ }^{3} \mathrm{~J}(\mathrm{H}, \mathrm{H})=7.1 \mathrm{~Hz}, 2 \mathrm{H} ; \mathrm{CH}_{2(\text { ester })}\right), 3.79\left(\mathrm{~s}, 3 \mathrm{H} ; \mathrm{CH}_{3(\mathrm{PMB})}\right)$, $3.52\left(\mathrm{~s}, 2 \mathrm{H} ; \mathrm{CH}_{2}-\mathrm{O}\right), 2.51-2.45\left(\mathrm{~m}, 4 \mathrm{H} ; \mathrm{CH}_{2}\right), 1.25 \mathrm{ppm}\left(\mathrm{t},{ }^{3} \mathrm{~J}(\mathrm{H}, \mathrm{H})=\right.$ $\left.7.1 \mathrm{~Hz}, 3 \mathrm{H} ; \mathrm{CH}_{3(\text { ester })}\right) ;{ }^{13} \mathrm{C} \mathrm{NMR}\left(126 \mathrm{MHz} \mathrm{CDCl}_{3}\right): \delta=172.1,159.3$, 130.3, 129.4 (2C), 113.9 (2C), 78.7, 77.4, 75.4, 75.1, 72.7, 68.1, 60.7, 55.4, 33.7, 19.7 (quint, ${ }^{1} J(C, D)=20.5 \mathrm{~Hz}$ ), 14.8, 14.3, 9.4 ppm (quint, $\left.{ }^{1} J(C, D)=20.3 \mathrm{~Hz}\right)$; HRMS (ASAP+): $\mathrm{m} / \mathrm{z}$ calcd for $\mathrm{C}_{20} \mathrm{H}_{20} \mathrm{D}_{4} \mathrm{O}_{4}$ : $332.1926\left[\mathrm{M}^{+*}\right.$; found: 332.1922 .

\section{Ethyl 6,6,9,9-Tetradeutero-10-hydroxydeca-4,7-diynoate (18)}

2,3-Dichloro-5,6-dicyano-p-benzoquinone (DDQ; $1.88 \mathrm{~g}, 8.26 \mathrm{mmol}$ ) was added to a solution of protected alcohol $17(1.92 \mathrm{~g}$, $5.78 \mathrm{mmol})$ in $\mathrm{CH}_{2} \mathrm{Cl}_{2} /$ water $(10: 1,88 \mathrm{~mL})$ at $0{ }^{\circ} \mathrm{C}$. Then, the mixture was stirred at $0^{\circ} \mathrm{C}$ for $4 \mathrm{~h}$ and quenched with a saturated aqueous solution of $\mathrm{NaHCO}_{3}(200 \mathrm{~mL})$. The layers were separated and the aqueous layer was extracted with EtOAc $(3 \times 100 \mathrm{~mL})$. The combined organic layers were dried over $\mathrm{Na}_{2} \mathrm{SO}_{4}$, filtered, and the solvents were removed under reduced pressure. The residue was purified by column chromatography on silica gel (6:4 n-pentane/Et $\left.{ }_{2} \mathrm{O}\right)$ to give deprotected alcohol $18(1.14 \mathrm{~g}, 94 \%$ yield) as a pale-yellow oil.

$R_{\mathrm{f}}=0.43$ (n-pentane/EtOAc, $\left.1: 1\right) ;{ }^{1} \mathrm{H}$ NMR $\left(500 \mathrm{MHz}, \mathrm{CDCl}_{3}\right): \delta=4.15$ (q, $\left.{ }^{3} \mathrm{~J}(\mathrm{H}, \mathrm{H})=7.1 \mathrm{~Hz}, 2 \mathrm{H} ; \mathrm{CH}_{2(\text { ester }}\right), 3.69\left(\mathrm{~d},{ }^{3} \mathrm{~J}(\mathrm{H}, \mathrm{H})=6.2 \mathrm{~Hz}, 2 \mathrm{H} ; \mathrm{CH}_{2}-\right.$ O), $2.52-2.45\left(\mathrm{~m}, 4 \mathrm{H} ; \mathrm{CH}_{2}\right), 1.85\left(\mathrm{t},{ }^{3} \mathrm{~J}(\mathrm{H}, \mathrm{H})=6.2 \mathrm{~Hz}, 1 \mathrm{H} ; \mathrm{OH}\right)$, $1.26 \mathrm{ppm} \quad\left(\mathrm{t},{ }^{3} \mathrm{~J}(\mathrm{H}, \mathrm{H})=7.1 \mathrm{~Hz}, \quad 3 \mathrm{H} ; \mathrm{CH}_{3(\text { ester })}\right) ;{ }^{13} \mathrm{C}$ NMR $\quad(126 \mathrm{MHz}$, $\left.\mathrm{CDCl}_{3}\right): \delta=172.2,78.8,77.4,76.6,75.0,61.1,60.7,33.7,22.7$ (quint, ${ }^{1} J(C, D)=20 \mathrm{~Hz}$ ), 14.8, 14.3, $9.5 \mathrm{ppm}$ (quint, ${ }^{\prime} J(C, D)=20.5 \mathrm{~Hz}$ ); HRMS (ASAP+): $\mathrm{m} / \mathrm{z}$ calcd for $\mathrm{C}_{12} \mathrm{H}_{13} \mathrm{D}_{4} \mathrm{O}_{3}: 213.1429[\mathrm{M}+\mathrm{H}]^{+}$; found: 213.1430.

\section{(4Z,7Z)-Ethyl 6,6,9,9-Tetradeutero-10-hydroxydeca-4,7-dien- oate (19)}

A solution of $\mathrm{NaBH}_{4}$ in $\mathrm{EtOH}(0.5 \mathrm{M}, 0.56 \mathrm{~mL})$ was added dropwise to a solution of $\mathrm{Ni}(\mathrm{OAc})_{2} \cdot 4 \mathrm{H}_{2} \mathrm{O}(38 \mathrm{mg}, 0.15 \mathrm{mmol})$ in $\mathrm{EtOH}(25 \mathrm{~mL})$ at $0^{\circ} \mathrm{C}$ under a hydrogen atmosphere. The mixture was stirred at $0^{\circ} \mathrm{C}$ for $15 \mathrm{~min}$ and a solution of ethylenediamine in $\mathrm{EtOH}(0.5 \mathrm{M}$, $1.88 \mathrm{~mL}$ ) was added. After a further $15 \mathrm{~min}$ at $0^{\circ} \mathrm{C}$, a solution of diyne $18(100 \mathrm{mg}, 0.47 \mathrm{mmol})$ in $\mathrm{EtOH}(15 \mathrm{~mL})$ was added. Before and after each addition of the reagent, three cycle of vacuum $/ \mathrm{H}_{2}$ addition were performed. The reaction was stirred for $40 \mathrm{~min}$ at $0^{\circ} \mathrm{C}$ under a hydrogen atmosphere and then quenched with a saturated aqueous solution of $\mathrm{NH}_{4} \mathrm{Cl}(15 \mathrm{~mL})$ and brine $(20 \mathrm{~mL})$. The aqueous layer was extracted with EtOAc $(3 \times 30 \mathrm{~mL})$. The combined organic layers were dried over $\mathrm{Na}_{2} \mathrm{SO}_{4}$, filtered, and the solvents were removed under reduced pressure. The residue was purified by column chromatography on silica gel (6:4 n-pentane/ $\left.\mathrm{Et}_{2} \mathrm{O}\right)$ to give diene 19 (91 mg, 78\% yield) as a pale-yellow oil (with $12 \%$ of the over-reduced byproduct).

$R_{\mathrm{f}}=0.24$ (n-pentane/EtOAc, 6:4); ${ }^{1} \mathrm{H}$ NMR $\left(500 \mathrm{MHz}, \mathrm{CDCl}_{3}\right): \delta=5.52$ $\left(\mathrm{d},{ }^{3} \mathrm{~J}(\mathrm{H}, \mathrm{H})=10.5 \mathrm{~Hz}, 1 \mathrm{H} ; \mathrm{CD}_{2}-\mathrm{CH}=\mathrm{CH}-\mathrm{CD}_{2}\right), 5.41-5.34(\mathrm{~m}, 3 \mathrm{H} ; \mathrm{CH})$, $4.13\left(\mathrm{q},{ }^{3} \mathrm{~J}(\mathrm{H}, \mathrm{H})=7 \mathrm{~Hz}, 2 \mathrm{H} ; \mathrm{CH}_{2 \text { (ester })}\right), 3.64\left(\mathrm{~s}, 2 \mathrm{H} ; \mathrm{CH}_{2}-\mathrm{O}\right), 2.42-2.34$ $\left(\mathrm{m}, 4 \mathrm{H} ; \mathrm{CH}_{2}\right), 1.25 \mathrm{ppm}\left(\mathrm{t}, 3 \mathrm{~J}(\mathrm{H}, \mathrm{H})=7 \mathrm{~Hz}, 3 \mathrm{H} ; \mathrm{CH}_{3(\text { ester })}\right) ;{ }^{13} \mathrm{C} \mathrm{NMR}$ $\left(126 \mathrm{MHz}, \mathrm{CDCl}_{3}\right): \delta=173.3,130.4,129.0,127.9,125.8,61.9,60.4$, 34.2, 30.1 (quint, $\left.{ }^{1} J(C, D)=19.2 \mathrm{~Hz}\right), 25.7-24.9(\mathrm{~m}), 22.8,14.2 \mathrm{ppm}$; 
HRMS (ESI+): $\mathrm{m} / z$ calcd for $\mathrm{C}_{12} \mathrm{H}_{17} \mathrm{D}_{4} \mathrm{O}_{3}: 217.1742[\mathrm{M}+\mathrm{H}]^{+}$; found: 217.1741.

\section{(4Z,7Z)-Ethyl 6,6,9,9-Tetradeutero-10-iododeca-4,7-dienoate $\left(19^{\prime}\right)$}

Imidazole $(429 \mathrm{mg}, 6.30 \mathrm{mmol})$ and triphenylphosphine $(826 \mathrm{mg}$, $3.15 \mathrm{mmol}$ ) were added to a solution of $\mathrm{I}_{2}(800 \mathrm{mg}, 3.15 \mathrm{mmol})$ in $\mathrm{CH}_{2} \mathrm{Cl}_{2}(7 \mathrm{~mL})$ under an inert atmosphere. The mixture was cooled to $0^{\circ} \mathrm{C}$ and a solution of alcohol $19(447 \mathrm{mg}, 2.10 \mathrm{mmol})$ in $\mathrm{CH}_{2} \mathrm{Cl}_{2}$ $(7 \mathrm{~mL})$ was added. After the addition was complete, the reaction mixture was allowed to warm to RT and stirred for a further $4 \mathrm{~h}$. Then, the reaction was quenched with a saturated aqueous solution of $\mathrm{Na}_{2} \mathrm{~S}_{2} \mathrm{O}_{3}(20 \mathrm{~mL})$, water $(20 \mathrm{~mL})$, and $\mathrm{CH}_{2} \mathrm{Cl}_{2}(15 \mathrm{~mL})$. The layers were separated and the aqueous layer was extracted with $\mathrm{CH}_{2} \mathrm{Cl}_{2}(15 \mathrm{~mL})$. The combined organic layers were dried over $\mathrm{Na}_{2} \mathrm{SO}_{4}$, filtered, and the solvents were removed under reduced pressure. The residue was purified by column chromatography on silica gel ( $n$-pentane/ $\left.\mathrm{Et}_{2} \mathrm{O}, 95: 5\right)$ to give the iodide derivative (634 mg, 93\% yield) as a pale-yellow oil.

$R_{\mathrm{f}}=0.55$ ( $n$-pentane/EtOAc, 95:5); ${ }^{1} \mathrm{H} \mathrm{NMR}\left(500 \mathrm{MHz}, \mathrm{CDCl}_{3}\right): \delta=$ $5.49\left(\mathrm{~d},{ }^{3} \mathrm{~J}(\mathrm{H}, \mathrm{H})=11 \mathrm{~Hz}, 1 \mathrm{H} ; \mathrm{CD}_{2}-\mathrm{CH}-\mathrm{CH}-\mathrm{CD}_{2}\right), 5.38-5.33(\mathrm{~m}, 3 \mathrm{H}$; $\mathrm{CH}), 4.13\left(\mathrm{q},{ }^{3} \mathrm{~J}(\mathrm{H}, \mathrm{H})=7 \mathrm{~Hz}, 2 \mathrm{H} ; \mathrm{CH}_{2(\text { ester) }}\right), 3.12\left(\mathrm{~s}, 2 \mathrm{H} ; \mathrm{CH}_{2}-\mathrm{l}\right), 2.41-$ $2.33\left(\mathrm{~m}, 4 \mathrm{H} ; \mathrm{CH}_{2}\right), 1.25 \mathrm{ppm}\left(\mathrm{t},{ }^{3} \mathrm{~J}(\mathrm{H}, \mathrm{H})=7 \mathrm{~Hz}, 3 \mathrm{H} ; \mathrm{CH}_{3(\text { ester })}\right)$; ${ }^{13} \mathrm{C} \mathrm{NMR}\left(126 \mathrm{MHz}, \mathrm{CDCl}_{3}\right): \delta=173.2,130.4,128.8,128.4(2 \mathrm{C}), 60.5$, 34.3, 30.9 (quint, ${ }^{1} J(C, D)=19.7 \mathrm{~Hz}$ ), 25.3 (quint, ${ }^{1} J(C, D)=19.1 \mathrm{~Hz}$ ), 23.0, 14.4, $5.1 \mathrm{ppm}$; HRMS (ASAP+): $\mathrm{m} / \mathrm{z}$ calcd for $\mathrm{C}_{12} \mathrm{H}_{16} \mathrm{D}_{2} \mathrm{IO}_{2}$ : $327.0759[\mathrm{M}+\mathrm{H}]^{+}$; found: 327.0762 .

\section{(3Z,6Z)-(2,2,5,5-Tetradeutero-10-ethoxy-10-oxodeca-3,6-dien- 1-yl)triphenylphosphonium lodide (2b)}

Triphenylphosphine $(583 \mathrm{mg}, 2.22 \mathrm{mmol}$ ) was added to a solution of the iodide derivative $(604 \mathrm{mg}, 1.85 \mathrm{mmol})$ in $\mathrm{MeCN}(12 \mathrm{~mL})$ at RT under an inert atmosphere. The mixture was stirred at reflux for $17 \mathrm{~h}$ and the solvent was removed under reduced pressure. The residue was purified by column chromatography on silica gel $\left(\mathrm{CH}_{2} \mathrm{Cl}_{2} / \mathrm{MeOH}, 98: 2\right.$ to $\left.9: 1\right)$ to give phosphonium salt $\mathbf{2}$ b $(903 \mathrm{mg}$ quantitative yield) as a clear wax.

$R_{\mathrm{f}}=0.21\left(\mathrm{CH}_{2} \mathrm{Cl}_{2} / \mathrm{MeOH}, 95: 5\right) ;{ }^{1} \mathrm{H} \mathrm{NMR}\left(500 \mathrm{MHz}, \mathrm{CDCl}_{3}\right): \delta=7.83-$ $7.68\left(\mathrm{~m}, 15 \mathrm{H} ; \mathrm{CH}_{\mathrm{Ar}}\right), 5.57\left(\mathrm{~d},{ }^{3} \mathrm{~J}(\mathrm{H}, \mathrm{H})=10.5 \mathrm{~Hz}, 1 \mathrm{H} ; \mathrm{P}-\mathrm{CH}_{2}-\mathrm{CD}_{2}-\mathrm{CH}\right)$, $5.33\left(\mathrm{~d},{ }^{3} \mathrm{~J}(\mathrm{H}, \mathrm{H})=11 \mathrm{~Hz}, 1 \mathrm{H} ; \mathrm{P}-\mathrm{CH}_{2}-\mathrm{CD}_{2}-\mathrm{CH}=\mathrm{CH}\right), 5.28-5.23(\mathrm{~m}$, $\left.1 \mathrm{H} ; \mathrm{CH}=\mathrm{CH}_{2}\right), 5.19\left(\mathrm{~d},{ }^{3} \mathrm{~J}(\mathrm{H}, \mathrm{H})=11 \mathrm{~Hz}, 1 \mathrm{H} ; \mathrm{CH}=\mathrm{CH}-\mathrm{CH}_{2}\right), 4.03(\mathrm{q}$, $\left.{ }^{3} \mathrm{~J}(\mathrm{H}, \mathrm{H})=7 \mathrm{~Hz}, 2 \mathrm{H} ; \mathrm{CH}_{2(\text { ester })}\right), 3.66\left(\mathrm{~d},{ }^{2} \mathrm{~J}(\mathrm{H}, \mathrm{P})=12 \mathrm{~Hz}, 2 \mathrm{H} ; \mathrm{P}-\mathrm{CH}_{2}\right)$, 2.26-2.14 (m, $\left.4 \mathrm{H} ; \mathrm{CH}_{2}\right), 1.18 \mathrm{ppm}\left(\mathrm{t},{ }^{3} \mathrm{~J}(\mathrm{H}, \mathrm{H})=7.5 \mathrm{~Hz}, 3 \mathrm{H} ; \mathrm{CH}_{3 \text { (ester) }}\right)$; ${ }^{13} \mathrm{C} \mathrm{NMR}\left(126 \mathrm{MHz}, \mathrm{CDCl}_{3}\right): \delta=173.0,135.2\left(\mathrm{~d},{ }^{4} J(\mathrm{C}, \mathrm{P})=1.8 \mathrm{~Hz}, 3 \mathrm{C}\right)$, $133.6\left(d,{ }^{3} J(C, P)=9.9 \mathrm{~Hz}, 6 \mathrm{C}\right), 130.6\left(d,{ }^{2} J(C, P)=12.4 \mathrm{~Hz}, 6 \mathrm{C}\right), 130.4$ 128.4, 128.1, $126.2\left(d,{ }^{3} J(C, P)=15 \mathrm{~Hz}\right), 117.8\left(d,{ }^{1} J(C, P)=86 \mathrm{~Hz}, 3 \mathrm{C}\right)$, 60.3, 33.9, 24.9 (quint, ' $J(C, D)=19.2 \mathrm{~Hz}), 23.0\left(\mathrm{~d},{ }^{1} J(C, P)=48.7 \mathrm{~Hz}\right)$, 22.7, 20.0-19.5 (m), 14.3 ppm; ${ }^{31} \mathrm{P} \mathrm{NMR}\left(120 \mathrm{MHz}, \mathrm{CDCl}_{3}\right): \delta=$ $24.1 \mathrm{ppm}$; HRMS (ESI+): $\mathrm{m} / \mathrm{z}$ calcd for $\mathrm{C}_{30} \mathrm{H}_{30} \mathrm{D}_{4} \mathrm{O}_{2} \mathrm{P}: 461.2547$ $[M-1]^{+}$; found: 461.2549 .

\section{Extraction of EPA from Cod Liver Oil}

Commercial cod liver oil (7.00 g; Cooper, France) was dissolved in a mixture of $\mathrm{EtOH} /$ water $(95: 5,35 \mathrm{~mL})$ in the presence of $\mathrm{NaOH}$ $(2.1 \mathrm{~g})$ under an argon atmosphere. The mixture was protected from light by using aluminum foil and heated at $82^{\circ} \mathrm{C}$ for $2 \mathrm{~h}$. The ethanolic fraction was evaporated under reduced pressure and the residue was dissolved in $n$-hexane $(40 \mathrm{~mL})$ after heating. Then, water $(35 \mathrm{~mL}$ ) was added to the organic layer and the unsaponifiable material was removed by repeated extraction of the aqueous phase with $n$-hexane $(4 \times 40 \mathrm{~mL})$. The aqueous phase was acidified to $\mathrm{pH} 2$ by using an aqueous solution of $\mathrm{HCl}(6.0 \mathrm{M})$. The fatty acids were extracted with $n$-hexane $(4 \times 35 \mathrm{~mL})$ and the organic phase was concentrated under reduced pressure to give the crude fatty acids $(6.47 \mathrm{~g})$ as an oil. Urea $(19.40 \mathrm{~g})$ and EtOH $(80 \mathrm{~mL})$ were added to the crude residue. The mixture was protected from light by using aluminum foil and heated at $60-70^{\circ} \mathrm{C}$ until it turned into a homogeneous clear solution. The mixture was allowed to cool to RT and then cooled at $4{ }^{\circ} \mathrm{C}$ for $24 \mathrm{~h}$. The resulting crystals were separated from the liquid by filtration. The filtrate was diluted with water $(50 \mathrm{~mL})$ and acidified to $\mathrm{pH} \mathrm{4-5}$ with an aqueous solution of $\mathrm{HCl}(6.0 \mathrm{M}) . n$-Hexane $(100 \mathrm{~mL})$ was added and the solution was thoroughly stirred for $1 \mathrm{~h}$. The $n$-hexane layer that contained the liberated fatty acids was separated from the aqueous layer and washed with water $(3 \times 60 \mathrm{~mL})$. The organic phase was dried with $\mathrm{Na}_{2} \mathrm{SO}_{4}$ and concentrated under reduced pressure to give a crude mixture of PUFAs $(820 \mathrm{mg})$, which was purified by preparative HPLC (column: Atlantis Prep OBDTM; particle size: $10 \mu \mathrm{m}$; dimensions: $19 \mathrm{~mm} \times 250 \mathrm{~mm}$; water/MeOH, $13: 87$; isocratic flow; photodiode array detector (PDA) detection: $217 \mathrm{~nm}$ ) to give pure EPA (1.33 g).

$R_{\mathrm{f}}=0.21$ ( $n$-pentane/EtOAc, 8:2); ${ }^{1} \mathrm{H} \mathrm{NMR}\left(500 \mathrm{MHz}, \mathrm{CDCl}_{3}\right): \delta=$

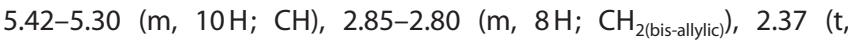
$\left.{ }^{3} \mathrm{~J}(\mathrm{H}, \mathrm{H})=7.5 \mathrm{~Hz}, 2 \mathrm{H} ; \mathrm{CH}_{2}-\mathrm{CO}\right), 2.14-2.05\left(\mathrm{~m}, 4 \mathrm{H} ; \mathrm{CH}_{2}-\mathrm{CH}_{2}-\mathrm{CH}_{2}-\mathrm{CO}\right.$ and $\left.\mathrm{CH}_{2}-\mathrm{CH}_{3}\right), 1.75-1.69\left(\mathrm{~m}, 2 \mathrm{H} ; \mathrm{CH}_{2}-\mathrm{CH}_{2}-\mathrm{CO}\right), 0.97 \mathrm{ppm}$ (t, $\left.{ }^{3} \mathrm{~J}(\mathrm{H}, \mathrm{H})=7.5 \mathrm{~Hz}, 3 \mathrm{H} ; \mathrm{CH}_{3}\right)$.

\section{Methyl 4-(3-((2Z,5Z,8Z,11Z)-Tetradeca-2,5,8,11-tetraen-1-yl)ox- iran-2-yl)butanoate (21)}

$\gamma$-Collidine (2,4,6-trimethylpyridine, $0.26 \mathrm{~mL}, 2 \mathrm{mmol})$ and $I_{2}$ (250 mg, $1 \mathrm{mmol}$ ) were added to a solution of eicosapentaenoic acid (EPA; $150 \mathrm{mg}, 0.50 \mathrm{mmol})$ in $\mathrm{MeCN}(15 \mathrm{~mL})$ at $0^{\circ} \mathrm{C}$ under an inert atmosphere. The mixture was stirred for $1 \mathrm{~h}$ at $0^{\circ} \mathrm{C}$ and then quenched with a saturated aqueous solution of $\mathrm{Na}_{2} \mathrm{~S}_{2} \mathrm{O}_{3}(10 \mathrm{~mL})$ and EtOAc $(30 \mathrm{~mL})$. The layers were separated and the organic layer was washed with brine $(3 \times 20 \mathrm{~mL})$ and water $(10 \mathrm{~mL})$. The combined organic layers were dried over $\mathrm{Na}_{2} \mathrm{SO}_{4}$, filtered, and the solvents were removed under reduced pressure. The crude iodolactone was immediately used in the next step without further purification.

$\mathrm{K}_{2} \mathrm{CO}_{3}(150 \mathrm{mg}, 0.90 \mathrm{mmol})$ was added to a solution of the crude iodolactone $(400 \mathrm{mg})$ in $\mathrm{MeOH}(10 \mathrm{~mL})$ at RT under an inert atmosphere. The mixture was stirred for $4 \mathrm{~h}$ at RT and quenched with brine $(15 \mathrm{~mL})$ and water $(20 \mathrm{~mL})$. The aqueous layer was extracted with $n$-pentane $(4 \times 30 \mathrm{~mL})$. The combined organic layers were dried over $\mathrm{Na}_{2} \mathrm{SO}_{4}$, filtered, and the solvents were removed under reduced pressure. The residue was purified by column chromatography on silica gel ( $n$-pentane/EtOAc, 95:5) to give epoxide 21 (158 $\mathrm{mg}, 95 \%$ yield) as a pale-yellow oil.

$R_{\mathrm{f}}=0.25$ (n-pentane/EtOAc, 9:1); ${ }^{1} \mathrm{H} \mathrm{NMR}\left(500 \mathrm{MHz}, \mathrm{CDCl}_{3}\right): \delta=$ 5.53-5.27 (m, 8H; CH), $3.66\left(\mathrm{~s}, 3 \mathrm{H} ; \mathrm{CH}_{3 \text { (ester })}\right), 2.95-2.92(\mathrm{~m}, 2 \mathrm{H}$; $\left.\mathrm{CH}_{\text {(epoxide) }}\right), 2.84-2.78\left(\mathrm{~m}, 6 \mathrm{H} ; \mathrm{CH}_{\text {(bis-allylic) }}\right), 2.41-2.35\left(\mathrm{~m}, 3 \mathrm{H} ; \mathrm{CH}_{2}-\mathrm{CO}\right.$ and $\left.\mathrm{CH}-\mathrm{CH}_{2(\mathrm{a})}-\mathrm{CH}_{\text {(epoxide) }}\right), 2.24-2.18\left(\mathrm{~m}, 1 \mathrm{H} ; \mathrm{CH}-\mathrm{CH}_{2(\mathrm{~b})}-\mathrm{CH}_{\text {(epoxide) }}\right)$, 2.08-2.05 (m, 2H; CH- $\left.\mathrm{CH}_{2}-\mathrm{CH}_{3}\right), 1.86-1.77\left(\mathrm{~m}, 2 \mathrm{H} ; \mathrm{CH}_{2}-\mathrm{CH}_{2}-\mathrm{CH}_{2}\right)$, 1.86-1.77 (m, 2 H; $\left.\mathrm{CH}_{\text {(epoxide) }}-\mathrm{CH}_{2}-\mathrm{CH}_{2}\right), 0.96 \mathrm{ppm}\left(\mathrm{t},{ }^{3} \mathrm{~J}(\mathrm{H}, \mathrm{H})=7.5 \mathrm{~Hz}\right.$, $\left.3 \mathrm{H} ; \mathrm{CH}_{3}\right) ;{ }^{13} \mathrm{C} \mathrm{NMR}\left(125 \mathrm{MHz}, \mathrm{CDCl}_{3}\right): \delta=173.8,132.2,130.7,128.7$, $128.6,127.8,127.8,127.1,124.4,56.7,56.3,51.7,33.7,27.3,26.3$, $25.9,25.7,25.6,22.1,20.7,14.4 \mathrm{ppm}$. 


\section{(3Z,6Z,9Z, 12Z)-Pentadeca-3,6,9,12-tetraenal (3a)}

Acetic anhydride $(9 \mathrm{~mL})$ was added to a solution of epoxide 21 $(4.48 \mathrm{~g}, 13.47 \mathrm{mmol})$ in acetic acid $(90 \mathrm{~mL})$ at RT under an inert atmosphere. The mixture was stirred at $45^{\circ} \mathrm{C}$ for $2.5 \mathrm{~d}$ and the solvents were removed under reduced pressure. The crude diacetate was immediately used in the next step without further purification. A solution of $\mathrm{LiOH} \cdot \mathrm{H}_{2} \mathrm{O}(2.70 \mathrm{~g}, 64.35 \mathrm{mmol})$ in water $(100 \mathrm{~mL})$ was added to a solution of the diacetate in $\mathrm{MeOH}(100 \mathrm{~mL})$ at $\mathrm{RT}$ under an inert atmosphere. The mixture was stirred at RT for $21 \mathrm{~h}$, cooled to $0{ }^{\circ} \mathrm{C}$, and carefully quenched with an aqueous solution of $\mathrm{HCl}$ $(10 \%)$ to $\mathrm{pH}$ 1. The aqueous layer was extracted with $\mathrm{Et}_{2} \mathrm{O}(2 \times$ $100 \mathrm{~mL}$ ). The combined organic layers were dried over $\mathrm{Na}_{2} \mathrm{SO}_{4}$, filtered, and the solvents were removed under reduced pressure. The crude diol was immediately used in the next step without further purification.

A solution of sodium periodate $(6.68 \mathrm{~g}, 31.23 \mathrm{mmol})$ in water $(49 \mathrm{~mL})$ was added dropwise to a solution of the crude diol in $\mathrm{MeOH}(180 \mathrm{~mL})$ at $\mathrm{RT}$ under an inert atmosphere. The mixture was stirred at RT for $3 \mathrm{~h}$ and then quenched with brine $(150 \mathrm{~mL})$. The aqueous layer was extracted with $n$-pentane $(3 \times 100 \mathrm{~mL})$ and the combined organic layers were successively washed with a saturated aqueous solution of $\mathrm{NaHCO}_{3}(100 \mathrm{~mL})$, brine, and water. The organic layer was dried over $\mathrm{Na}_{2} \mathrm{SO}_{4}$, filtered, and the solvents were removed under reduced pressure. Then, the residue was dissolved in $\mathrm{Et}_{2} \mathrm{O}(10 \mathrm{~mL})$ and finally filtered through a plug of Celite ${ }^{\circledR}$ and the solvents were removed under reduced pressure to give crude aldehyde 3 a $(2.57 \mathrm{~g}, 87 \%$ yield). Purification by column chromatography on normal-phase silica gel was not possible because of isomerization of the desired aldehyde into the $\alpha, \beta$-unsaturated aldehyde.

$R_{\mathrm{f}}=0.47$ (n-pentane/EtOAc, 9:1); ${ }^{1} \mathrm{H}$ NMR $\left(500 \mathrm{MHz}, \mathrm{CDCl}_{3}\right): \delta=9.68$ $\left(\mathrm{t},{ }^{3} \mathrm{~J}(\mathrm{H}, \mathrm{H})=2 \mathrm{~Hz}, 1 \mathrm{H} ; \mathrm{CHO}\right), 5.72-5.67(\mathrm{~m}, 1 \mathrm{H} ; \mathrm{CH}), 5.62-5.56(\mathrm{~m}$, $1 \mathrm{H} ; \mathrm{CH}), 5.44-5.28(\mathrm{~m}, 6 \mathrm{H} ; \mathrm{CH}), 3.24-3.22\left(\mathrm{~m}, 2 \mathrm{H} ; \mathrm{CH}_{2}-\mathrm{CHO}\right)$,

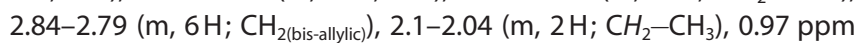
$\left(\mathrm{t}^{3} \mathrm{~J}(\mathrm{H}, \mathrm{H})=7.5 \mathrm{~Hz}, 3 \mathrm{H} ; \mathrm{CH}_{3}\right) ;{ }^{13} \mathrm{C}$ NMR $\left(126 \mathrm{MHz}_{1} \mathrm{CDCl}_{3}\right): \delta=199.5$, $133.3,132.3,129.0,128.9,127.7,127.2,127.1,118.8,42.6,26.1,25.8$, $25.7,20.7,14.4 \mathrm{ppm}$.

\section{(3Z,6Z,9Z,12Z)-Pentadeca-3,6,9,12-tetraen-1-ol (22)}

$\mathrm{NaBH}_{4}(1.47 \mathrm{~g}, 38.86 \mathrm{mmol})$ was added to a solution of aldehyde $3 \mathrm{a}(2.30 \mathrm{~g}$ of the crude product, $10.53 \mathrm{mmol})$ in $\mathrm{MeOH}(70 \mathrm{~mL})$ at $0{ }^{\circ} \mathrm{C}$ under an inert atmosphere. The mixture was stirred at $0{ }^{\circ} \mathrm{C}$ for $1 \mathrm{~h}$ and then quenched with brine $(150 \mathrm{~mL})$. The aqueous layer was extracted with $\mathrm{CH}_{2} \mathrm{Cl}_{2}(3 \times 80 \mathrm{~mL})$. The combined organic layers were dried over $\mathrm{Na}_{2} \mathrm{SO}_{4}$, filtered, and the solvents were removed under reduced pressure. The residue was purified by column chromatography on silica gel ( $n$-pentane/ $\mathrm{Et}_{2} \mathrm{O}, 9: 1$ to $7: 3$ ) to give alcohol 22 ( $1.64 \mathrm{~g}, 71 \%$ yield) as a colorless oil.

$R_{\mathrm{f}}=0.18$ (n-pentane/EtOAc, 9:1); ${ }^{1} \mathrm{H} \mathrm{NMR}\left(500 \mathrm{MHz}, \mathrm{CDCl}_{3}\right): \delta=$ 5.58-5.53 $(\mathrm{m}, 1 \mathrm{H} ; \mathrm{CH}), 5.44-5.29(\mathrm{~m}, 7 \mathrm{H} ; \mathrm{CH}), 3.66(\mathrm{t}, 3 \mathrm{~J}(\mathrm{H}, \mathrm{H})=$

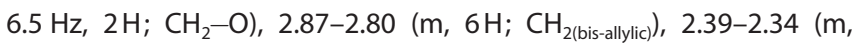
$\left.2 \mathrm{H} ; \mathrm{CH}_{2}-\mathrm{CH}_{2}-\mathrm{O}\right), 2.10-2.04\left(\mathrm{~m}, 2 \mathrm{H} ; \mathrm{CH}_{2}-\mathrm{CH}_{3}\right), 0.97 \mathrm{ppm}$ (t, $\left.{ }^{3} \mathrm{~J}(\mathrm{H}, \mathrm{H})=6.5 \mathrm{~Hz}, 3 \mathrm{H} ; \mathrm{CH}_{3}\right) ;{ }^{13} \mathrm{C} \mathrm{NMR}\left(126 \mathrm{MHz}, \mathrm{CDCl}_{3}\right): \delta=132.2$, $131.3,128.8,128.5,128.1,128.0,127.1,125,8,62.4,31.0,25.9,25.8$, $25.7,20.7,14.4 \mathrm{ppm}$.

\section{2-(3-((2Z,5Z,8Z)-Undeca-2,5,8-trien-1-yl)oxiran-2-yl) Ethanol} (23)

Vanadyl acetylacetonate $(100 \mathrm{mg}, 0.37 \mathrm{mmol})$ was added to a solution of homoallylic alcohol $22(1.64 \mathrm{~g}, 7.44 \mathrm{mmol})$ in toluene
$(60 \mathrm{~mL})$ at $0^{\circ} \mathrm{C}$ under an inert atmosphere. The mixture was stirred at $0^{\circ} \mathrm{C}$ for $5 \mathrm{~min}$ and a solution of $\mathrm{tBuOOH}(5.5 \mathrm{M}$ in $n$-decane, $2.7 \mathrm{~mL}$ ) was added dropwise. The mixture was stirred at RT for $1.5 \mathrm{~h}$ and a second portion of $\mathrm{tBuOOH}$ was added. The mixture was stirred for $4.5 \mathrm{~h}$ and then quenched with an aqueous solution of $\mathrm{Na}_{2} \mathrm{~S}_{2} \mathrm{O}_{3}(20 \%, 100 \mathrm{~mL})$ and water $(100 \mathrm{~mL})$. The aqueous layer was extracted with $\mathrm{CH}_{2} \mathrm{Cl}_{2}(3 \times 60 \mathrm{~mL})$. The combined organic layers were dried over $\mathrm{Na}_{2} \mathrm{SO}_{4}$, filtered, and the solvents were removed under reduced pressure. The residue was purified by column chromatography on silica gel ( $n$-pentane/EtOAc, 9:1 to 7:3) to give epoxide 23 ( $1.29 \mathrm{~g}, 73 \%$ yield) as a pale-yellow oil.

$R_{\mathrm{f}}=0.26$ ( $n$-pentane/EtOAc, 6:4); ${ }^{1} \mathrm{H}$ NMR $\left(500 \mathrm{MHz}, \mathrm{CDCl}_{3}\right): \delta=$ 5.54-5.28 (m, 6 H; CH), 3.90-3.82 (m, 2H; $\left.\mathrm{CH}_{2}-\mathrm{O}\right), 3.11\left(\mathrm{dt},{ }^{3} \mathrm{~J}(\mathrm{H}, \mathrm{H})=\right.$ $\left.4.5,8 \mathrm{~Hz}, 1 \mathrm{H} ; \mathrm{CH}_{\text {(epoxide) }}\right), 3.01-2.97\left(\mathrm{~m}, 1 \mathrm{H} ; \mathrm{CH}_{\text {(epoxide) }}\right), 2.85-2.79(\mathrm{~m}$, $\left.4 \mathrm{H} ; \mathrm{CH}_{2(\text { bis-allylic })}\right), 2.46-2.40\left(\mathrm{~m}, 1 \mathrm{H} ; \mathrm{CH}-\mathrm{CH}_{2(\mathrm{a})}-\mathrm{CH}_{\text {(epoxide) }}\right), 2.28-2.22$ $\left(\mathrm{m}, 1 \mathrm{H} ; \mathrm{CH}-\mathrm{CH}_{2(\mathrm{~b})}-\mathrm{CH}_{\text {(epoxide) }}\right), 2.10-2.03\left(\mathrm{~m}, 2 \mathrm{H} ; \mathrm{CH}_{2}-\mathrm{CH}_{3}\right), 1.93-$ $1.85\left(\mathrm{~m}, 1 \mathrm{H} ; \mathrm{CH}_{\text {(epoxide) }}-\mathrm{CH}_{2(\mathrm{~b})}-\mathrm{CH}_{2}\right), 1.77-1.70\left(\mathrm{~m}, 1 \mathrm{H} ; \mathrm{CH}_{\text {(epoxide) }}-\right.$ $\left.\mathrm{CH}_{2(\mathrm{a})}-\mathrm{CH}_{2}\right), \quad 0.97 \mathrm{ppm} \quad\left(\mathrm{t},{ }_{3} \mathrm{~J}(\mathrm{H}, \mathrm{H})=7.5 \mathrm{~Hz}, \quad 3 \mathrm{H} ; \mathrm{CH}_{3}\right) ;{ }^{13} \mathrm{C} \mathrm{NMR}$ $\left(126 \mathrm{MHz}_{1} \mathrm{CDCl}_{3}\right): \delta=132.3,130.9,129.0,127.5,127.0,124.1,60.8$, $56.1,55.1,30.6,26.5,25.9,25.7,20.7,14.4$ ppm.

\section{(3Z,6Z,9Z)-Dodeca-3,6,9-trienal (3 b)}

Acetic anhydride $(0.74 \mathrm{~mL})$ was added to a solution of epoxide 23 $(200 \mathrm{mg}, 0.85 \mathrm{mmol})$ in acetic acid $(7.40 \mathrm{~mL})$ at RT under an inert atmosphere. The mixture was stirred at $45^{\circ} \mathrm{C}$ for $23 \mathrm{~h}$ and the solvents were removed under reduced pressure. The residue, which was mainly composed of diacetate derivatives, was immediately used in the next step without further purification.

A solution of $\mathrm{LiOH} \cdot \mathrm{H}_{2} \mathrm{O}(93 \mathrm{mg}, 2.21 \mathrm{mmol})$ in water $(2.50 \mathrm{~mL})$ was added to a solution of the crude residue in $\mathrm{MeOH}(2.50 \mathrm{~mL})$ at RT under an inert atmosphere. The mixture was stirred at RT for $3 \mathrm{~h}$, cooled to $0{ }^{\circ} \mathrm{C}$, and carefully quenched with an aqueous solution of $\mathrm{HCl}(10 \%)$ to $\mathrm{pH} 1$ and then with water $(10 \mathrm{~mL})$. The aqueous layer was extracted with $\mathrm{Et}_{2} \mathrm{O}(3 \times 10 \mathrm{~mL})$. The combined organic layers were dried over $\mathrm{Na}_{2} \mathrm{SO}_{4}$, filtered, and the solvents were removed under reduced pressure. The crude triol was immediately used in the next step without further purification.

A solution of sodium periodate $(309 \mathrm{mg}, 1.44 \mathrm{mmol})$ in water $(2.30 \mathrm{~mL})$ was added dropwise to a solution of the crude triol in $\mathrm{MeOH}(8.90 \mathrm{~mL})$ at $\mathrm{RT}$ under an inert atmosphere. The mixture was stirred at RT for $2.5 \mathrm{~h}$ and then quenched with brine $(15 \mathrm{~mL})$. The aqueous layer was extracted with $n$-pentane $(3 \times 10 \mathrm{~mL})$. The combined organic layers were successively washed with a saturated aqueous solution of $\mathrm{NaHCO}_{3}(2 \times 20 \mathrm{~mL})$, brine, and water. The organic layer was dried over $\mathrm{Na}_{2} \mathrm{SO}_{4}$, filtered, and the solvents were removed under reduced pressure. The residue was dissolved in $\mathrm{Et}_{2} \mathrm{O}(10 \mathrm{~mL})$ and finally filtered through a plug of Celite ${ }^{\circledR}$. The solvents were removed under reduced pressure to give crude aldehyde $\mathbf{3 b}$ ( $93 \mathrm{mg}, 62 \%$ yield). The product must not be purified by column chromatography on normal-phase silica gel because of degradation.

$R_{\mathrm{f}}=0.50\left(n\right.$-pentane/EtOAc, 9:1); ${ }^{1} \mathrm{H}$ NMR $\left(500 \mathrm{MHz}, \mathrm{CDCl}_{3}\right): \delta=9.67$ $\left(\mathrm{t},{ }^{3} \mathrm{~J}(\mathrm{H}, \mathrm{H})=2 \mathrm{~Hz}, 1 \mathrm{H} ; \mathrm{CHO}\right), 5.71-5.66(\mathrm{~m}, 1 \mathrm{H} ; \mathrm{CH}), 5.61-5.55(\mathrm{~m}$, $1 \mathrm{H} ; \mathrm{CH}), 5.43-5.26(\mathrm{~m}, 4 \mathrm{H} ; \mathrm{CH}), 3.24-3.21\left(\mathrm{~m}, 2 \mathrm{H} ; \mathrm{CH}_{2}-\mathrm{CHO}\right)$,

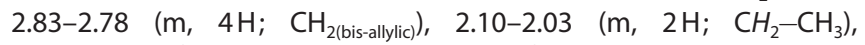
$0.97 \mathrm{ppm}\left(\mathrm{t},{ }^{3} \mathrm{~J}(\mathrm{H}, \mathrm{H})=7.5 \mathrm{~Hz}, 3 \mathrm{H} ; \mathrm{CH}_{3}\right) ;{ }^{13} \mathrm{C} \mathrm{NMR}\left(126 \mathrm{MHz}, \mathrm{CDCl}_{3}\right)$ : $\delta=199.3,133.2,132.2,129.2,126.9,126.8,118.7,42.5,26.0,25.6$, 20.6, $14.3 \mathrm{ppm}$. 
(4Z,7Z,10Z,13Z,16Z,19Z)-Ethyl 6,6-Dideuterodocosa$4,7,10,13,16,19$-hexaenoate (24a)

A solution of sodium bis(trimethylsilyl)amide (NaHMDS; $2.0 \mathrm{M}$ in THF, $0.50 \mathrm{~mL}$ ) was added dropwise to a solution of the deuterated phosphonium salt $(2 \mathrm{a} ; 548 \mathrm{mg}, 1 \mathrm{mmol})$ in THF $(9 \mathrm{~mL})$ at $-50^{\circ} \mathrm{C}$ under an inert atmosphere. Then, the reaction was stirred at $-20^{\circ} \mathrm{C}$ for $30 \mathrm{~min}$ and cooled to $-78^{\circ} \mathrm{C}$. A solution of aldehyde $3 \mathrm{a}$ (371 $\mathrm{mg}, 1.7 \mathrm{mmol}$ ) in THF $\left(9 \mathrm{~mL}\right.$ ) was cooled to $-78^{\circ} \mathrm{C}$ and added through a cannula to the orange mixture. The reaction was allowed to warm to RT over $1.5 \mathrm{~h}$ and then stirred for a further $21 \mathrm{~h}$. The reaction was quenched with a saturated aqueous solution of $\mathrm{NH}_{4} \mathrm{Cl}(30 \mathrm{~mL})$. The aqueous layer was extracted with $n$-pentane/ EtOAc $(8: 2,4 \times 20 \mathrm{~mL})$. The combined organic layers were dried over $\mathrm{MgSO}_{4}$, filtered, and the solvents were removed under reduced pressure. The residue was purified by column chromatography on silica gel (n-pentane/ $\left.\mathrm{Et}_{2} \mathrm{O}, 98: 2\right)$ to give the deuterated DHA ethyl ester (24a; $143 \mathrm{mg}, 40 \%$ yield) as a yellow oil.

$R_{\mathrm{f}}=0.51$ ( $n$-pentane/EtOAc, 9:1); ${ }^{1} \mathrm{H} \mathrm{NMR}\left(500 \mathrm{MHz}, \mathrm{CDCl}_{3}\right): \delta=$ 5.40-5.29 (m, 12 H; CH), $4.12\left(\mathrm{q},{ }^{3} \mathrm{~J}(\mathrm{H}, \mathrm{H})=7 \mathrm{~Hz}, 2 \mathrm{H} ; \mathrm{CH}_{2 \text { (ester })}\right), 2.85-$ $2.79\left(\mathrm{~m}, 8 \mathrm{H} ; \mathrm{CH}_{2 \text { (bis-allylic) }}\right), 2.40-2.33\left(\mathrm{~m}, 4 \mathrm{H} ; \mathrm{CH}_{2}-\mathrm{CH}_{2}-\mathrm{CO}\right), 2.08-$ $2.04\left(\mathrm{~m}, 2 \mathrm{H} ; \mathrm{CH}_{2}-\mathrm{CH}_{3}\right), 1.25\left(\mathrm{t},{ }^{3} \mathrm{~J}(\mathrm{H}, \mathrm{H})=7 \mathrm{~Hz}, 3 \mathrm{H} ; \mathrm{CH}_{3(\text { ester })}\right)$, $0.96 \mathrm{ppm}\left(\mathrm{t},{ }^{3} \mathrm{~J}(\mathrm{H}, \mathrm{H})=7.5 \mathrm{~Hz}, 3 \mathrm{H} ; \mathrm{CH}_{3}\right) ;{ }^{13} \mathrm{C} \mathrm{NMR}\left(126 \mathrm{MHz}, \mathrm{CDCl}_{3}\right)$ : $\delta=173.2,132.1,129.2,128.6,128.3(2 \mathrm{C}), 128.3,128.2,128.2,128.1$ (2C), 128.0, 127.1, 60.4, 34.4, 25.7 (2C), 25.7, 25.6, 25.1 (quint, $\left.{ }^{1} J(C, D)=19.4 \mathrm{~Hz}\right), 22.9,20.7,14.4,14.3 \mathrm{ppm}$; HRMS (ASAP+): $\mathrm{m} / \mathrm{z}$ calcd for $\mathrm{C}_{24} \mathrm{H}_{35} \mathrm{D}_{2} \mathrm{O}_{2}$ : $359.2919[\mathrm{M}+\mathrm{H}]^{+}$; found: 359.2918 .

\section{(4Z,7Z,10Z,13Z,16Z,19Z)-6,6-Dideuterodocosa-4,7,10,13,16,19- hexaenoic Acid (1 a)}

A solution of $\mathrm{LiOH} \cdot \mathrm{H}_{2} \mathrm{O}(109 \mathrm{mg}, 2.60 \mathrm{mmol})$ in water $(1 \mathrm{~mL})$ was added to a solution of ester $24 \mathrm{a}(143 \mathrm{mg}, 0.40 \mathrm{mmol})$ in $\mathrm{EtOH}$ $(1 \mathrm{~mL})$ under an inert atmosphere. The mixture was heated at $65^{\circ} \mathrm{C}$ for $1 \mathrm{~h}$ and an additional portion of $\mathrm{LiOH} \cdot \mathrm{H}_{2} \mathrm{O}(50 \mathrm{mg}, 1.20 \mathrm{mmol}$ ) was added. After heating at $65^{\circ} \mathrm{C}$ for $7 \mathrm{~h}$, the reaction was cooled to RT and quenched with water $(10 \mathrm{~mL})$ and an aqueous solution of $\mathrm{HCl}(1.0 \mathrm{M})$ to $\mathrm{pH} 2$. The aqueous layer was extracted with $n$-pentane/EtOAc $(6: 4,3 \times 10 \mathrm{~mL})$. The combined organic layers were dried over $\mathrm{MgSO}_{4}$, filtered, and the solvents were removed under reduced pressure. The residue was purified by column chromatography on silica gel ( $n$-pentane/EtOAc, $9: 1$ to $7: 3)$ to give $\left(6,6-D_{2}\right)$ DHA (1 a; $98 \mathrm{mg}, 77 \%$ yield) as a yellow oil. A portion of this product was purified by preparative HPLC to remove trace amounts of over-reduced byproducts (column: Waters Symmetry $\operatorname{Prep}^{\mathrm{TM}}\left(\mathrm{C}_{18}\right)$; particle size: $7 \mu \mathrm{m}$; dimensions: $7.8 \mathrm{~mm} \times 300 \mathrm{~mm}$; water/MeCN, 17:83; isocratic flow; UV detection: $217 \mathrm{~nm}$ ) to give pure deuterated DHA.

$R_{\mathrm{f}}=0.50$ (n-pentane/EtOAc, 6:4); ${ }^{1} \mathrm{H} \mathrm{NMR}\left(500 \mathrm{MHz}, \mathrm{CDCl}_{3}\right): \delta=$

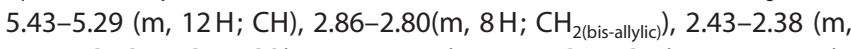
$\left.4 \mathrm{H} ; \mathrm{HC}-\mathrm{CH}_{2}-\mathrm{CH}_{2}-\mathrm{CO}\right), 2.10-2.04\left(\mathrm{~m}, 2 \mathrm{H} ; \mathrm{CH}_{2}-\mathrm{CH}_{3}\right), 0.97 \mathrm{ppm}(\mathrm{t}$, $\left.{ }^{3} \mathrm{~J}(\mathrm{H}, \mathrm{H})=7.5 \mathrm{~Hz}, 3 \mathrm{H} ; \mathrm{CH}_{3}\right) ;{ }^{13} \mathrm{C} \mathrm{NMR}\left(126 \mathrm{MHz}, \mathrm{CDCl}_{3}\right): \delta=179.5$, $132.2,129.6,128.7,128.5,128.4,128.4,128.2,128.2,128.0$ (2C), 127.7, 127.1, 34.1, $25.8(2 \mathrm{C}), 25.7,25.7,25.1$ (quint, $1 J(C, D)=$ $19.2 \mathrm{~Hz}), 22.6,20.7,14.4 \mathrm{ppm}$; HRMS (ESI-): $\mathrm{m} / \mathrm{z}$ calcd for $\mathrm{C}_{22} \mathrm{H}_{29} \mathrm{D}_{2} \mathrm{O}_{2}$ : $329.2450[\mathrm{M}-\mathrm{H}]^{-}$; found: 329.2446 ; HPLC (column: Bridge ${ }^{\circledR} \mathrm{BEH}\left(\mathrm{C}_{18}\right)$; particle size: $2.5 \mu \mathrm{m}$; dimensions: $2.1 \times 100 \mathrm{~mm}$; water $/ \mathrm{MeOH}, 20: 80$; isocratic flow; PDA detection: 200-800 nm): $t_{\mathrm{R}}=6.36 \mathrm{~min}$.

\section{$(4 Z, 7 Z, 10 Z, 13 Z, 16 Z, 19 Z)$-Ethyl 6,6,9,9-Tetradeuterodocosa- $4,7,10,13,16,19$-hexaenoate (24b)}

A solution of NaHMDS ( $2.0 \mathrm{M}$ in THF, $85 \mu \mathrm{L}$ ) was added dropwise to a solution of phosphonium salt $\mathbf{2 b}(100 \mathrm{mg}, 0.17 \mathrm{mmol})$ in THF $(1.50 \mathrm{~mL})$ at $-50^{\circ} \mathrm{C}$ under an inert atmosphere. The reaction was stirred at $-20^{\circ} \mathrm{C}$ for $30 \mathrm{~min}$ and then cooled to $-78^{\circ} \mathrm{C}$. A solution of aldehyde $\mathbf{3} \mathbf{b}(51 \mathrm{mg}, 1.70 \mathrm{mmol})$ in THF $(1.50 \mathrm{~mL})$ was cooled to $-78^{\circ} \mathrm{C}$ and added through a cannula to the orange mixture. The reaction was allowed to warm to RT over $1.5 \mathrm{~h}$ and then stirred for $21 \mathrm{~h}$. The reaction was quenched with a saturated aqueous solution of $\mathrm{NH}_{4} \mathrm{Cl}(10 \mathrm{~mL})$. The aqueous layer was extracted with $n$-pentane/EtOAc $(9: 1,4 \times 5 \mathrm{~mL})$. The combined organic layers were dried over $\mathrm{MgSO}_{4}$, filtered, and the solvents were removed under reduced pressure. The residue was purified by column chromatography on silica gel ( $n$-pentane/ $\mathrm{Et}_{2} \mathrm{O} 98: 2$ ) to give DHA ethyl ester $24 \mathrm{~b}$ (31 mg, $51 \%$ yield) as a yellow oil.

$R_{\mathrm{f}}=0.53$ (n-pentane/EtOAc, 9:1); ${ }^{1} \mathrm{H} \mathrm{NMR}\left(500 \mathrm{MHz}, \mathrm{CDCl}_{3}\right): \delta=$ 5.40-5.32 (m, 12 H; CH), $4.12\left(\mathrm{q},{ }^{3} J(\mathrm{H}, \mathrm{H})=7 \mathrm{~Hz}, 2 \mathrm{H} ; \mathrm{CH}_{2 \text { (ester) }}\right), 2.86-$

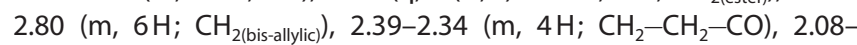
$2.05\left(\mathrm{~m}, 2 \mathrm{H} ; \mathrm{CH}_{2}-\mathrm{CH}_{3}\right), 1.25\left(\mathrm{t},{ }^{3} \mathrm{~J}(\mathrm{H}, \mathrm{H})=7 \mathrm{~Hz}, 3 \mathrm{H} ; \mathrm{CH}_{3(\text { ester })}\right)$, $0.97 \mathrm{ppm}\left(\mathrm{t},{ }^{3} \mathrm{~J}(\mathrm{H}, \mathrm{H})=7.5 \mathrm{~Hz}, 3 \mathrm{H} ; \mathrm{CH}_{3}\right) ;{ }^{13} \mathrm{C}$ NMR $\left(126 \mathrm{MHz}, \mathrm{CDCl}_{3}\right)$ : $\delta=173.2,132.1,129.2,128.7,128.4,128.3,128.2,128.2,128.1$ 128.1 (2C), 128.0, 127.1, 60.5, 34.4, 25.7, 25.7, 25.6, 25.1 (quint, ${ }^{1} J(C, D)=19.4 \mathrm{~Hz}$ ), $25.1 \quad$ (quint, $\left.{ }^{1} J(C, D)=19.5 \mathrm{~Hz}\right), 22.9,20.7,14.4$, 14.4 ppm; HRMS (ASAP+): $\mathrm{m} / \mathrm{z}$ calcd for $\mathrm{C}_{24} \mathrm{H}_{33} \mathrm{D}_{4} \mathrm{O}_{2}: 361.3045$ $[\mathrm{M}+\mathrm{H}]^{+}$; found: 361.3046 .

\section{(4Z,7Z,10Z,13Z, 16Z, 19Z)-6,6,9,9-Tetradeuterodocosa- 4,7,10,13,16,19-hexaenoic Acid (1 b)}

A solution of $\mathrm{LiOH} \cdot \mathrm{H}_{2} \mathrm{O}(72 \mathrm{mg}, 1.71 \mathrm{mmol})$ in water $(0.60 \mathrm{~mL})$ was added to a solution of ester $1 \mathbf{b}(95 \mathrm{mg}, 0.26 \mathrm{mmol})$ in $\mathrm{EtOH}$ $(0.6 \mathrm{~mL})$ under an inert atmosphere. The mixture was heated at $65^{\circ} \mathrm{C}$ for $4 \mathrm{~h}$ and an additional portion of $\mathrm{LiOH} \cdot \mathrm{H}_{2} \mathrm{O}(33 \mathrm{mg}$ $3 \mathrm{mmol}$ ) was added. After heating at $65^{\circ} \mathrm{C}$ for $7 \mathrm{~h}$, the reaction was cooled to RT and quenched with water $(10 \mathrm{~mL})$ and an aqueous solution of $\mathrm{HCl}(1.0 \mathrm{M})$ to $\mathrm{pH} 2$. The aqueous layer was extracted with $n$-pentane/EtOAc $(6: 4,3 \times 10 \mathrm{~mL})$. The combined organic layers were dried over $\mathrm{MgSO}_{4}$, filtered, and the solvents were removed under reduced pressure. The residue was purified by column chromatography on silica gel (n-pentane/EtOAc, 95:5 to 6:4) to give $\left(6,6,9,9-D_{4}\right)$-DHA ( 1 b; $72 \mathrm{mg}, 84 \%$ yield) as a yellow oil. A portion of this product was purified by preparative HPLC to remove trace amounts of over-reduced byproducts (column: Waters Symmetry Prep $^{\mathrm{TM}}\left(\mathrm{C}_{18}\right)$; particle size: $7 \mu \mathrm{m}$; dimensions: $7.8 \mathrm{~mm} \times 300 \mathrm{~mm}$; water/MeCN, 17:83; isocratic flow; UV detection: $217 \mathrm{~nm}$ ) to give pure deuterated DHA.

$R_{\mathrm{f}}=0.52$ (n-pentane/EtOAc, 6:4); ${ }^{1} \mathrm{H} \mathrm{NMR}\left(500 \mathrm{MHz}, \mathrm{CDCl}_{3}\right): \delta=$ 5.43-5.30 (m, $12 \mathrm{H} ; \mathrm{CH}), 2.86-2.80\left(\mathrm{~m}, 6 \mathrm{H} ; \mathrm{CH}_{2 \text { (bis-allylici }), 2.43-2.38}\right.$ $\left(\mathrm{m}, 4 \mathrm{H} ; \mathrm{CH}_{2}-\mathrm{CH}_{2}-\mathrm{CO}\right), 2.09-2.06\left(\mathrm{~m}, 2 \mathrm{H} ; \mathrm{CH}_{2}-\mathrm{CH}_{3}\right), 0.97 \mathrm{ppm}(\mathrm{t}$, $\left.{ }^{3} \mathrm{~J}(\mathrm{H}, \mathrm{H})=7.5 \mathrm{~Hz}, 3 \mathrm{H} ; \mathrm{CH}_{3}\right) ;{ }^{13} \mathrm{C} \mathrm{NMR}\left(126 \mathrm{MHz}, \mathrm{CDCl}_{3}\right): \delta=179.3$, 132.2, 129.6, 128.7, 128.4 (2C), 128.4, 128.2, 128.1, 128.1, 128.0, 127.7, 127.1, 34.1, 25.8, 25.8, 25.7, 25.1 (quint, ${ }^{1} J(C, D)=19.1 \mathrm{~Hz}$ ) 25.1 (quint, ${ }^{1} J(C, D)=19.5 \mathrm{~Hz}$ ), 22.6, 20.7, 14.4 ppm; HRMS (ESI-): $\mathrm{m} / \mathrm{z}$ calcd for $\mathrm{C}_{22} \mathrm{H}_{29} \mathrm{D}_{2} \mathrm{O}_{2}: 331.2575[\mathrm{M}-\mathrm{H}]^{-}$; found: 331.2574 ; HPLC (column: Bridge ${ }^{\circledR} \mathrm{BEH}\left(\mathrm{C}_{18}\right)$; particle size: $2.5 \mu \mathrm{m}$; dimensions: $2.1 \times$ $100 \mathrm{~mm}$; water/MeOH, 20:80; isocratic flow; PDA detection: 200$800 \mathrm{~nm}): t_{\mathrm{R}}=4.76 \mathrm{~min}$. 


\section{Acknowledgements}

This work was supported by the University of Montpellier through the PhD support for M.R.

Keywords: deuterium - DHA · lipids - total synthesis - Wittig reactions

[1] R. Uauy, E. Birch, D. Birch, P. Peirano, J. Pediatr. 1992, 120, S168-180.

[2] J. P. SanGiovanni, E. Y. Chew, Prog. Retinal Eye Res. 2005, 24, 87-138.

[3] A. P. Simopoulos, J. Am. Coll. Nutr. 2002, 21, 495-505.

[4] K. J. Bowen, W. S. Harris, P. M. Kris-Etherton, Curr. Treat. Options Cardiovasc. Med. 2016, 18, 69 .

[5] M. Hashimoto, S. Hossain, A. Al Mamun, K. Matsuzaki, H. Arai, Crit. Rev. Biotechnol. 2016, 1-19.

[6] a) T. Georgiou, A. Neokleous, D. Nicolaou, B. Sears, PharmaNutrition 2014, 2, 8-11; b) D. S. Rice, J. M. Calandria, W. C. Gordon, B. Jun, Y. Zhou, C. M. Gelfman, S. Li, M. Jin, E. J. Knott, B. Chang, A. Abuin, T. Issa, D. Potter, K. A. Platt, N. G. Bazan, Nat. Commun. 2015, 6, 6228.

[7] a) Age-Related Eye Disease Study 2 Research Group, JAMA 2013, 309, 2005-2015; b) F. Li, L. D. Marchette, R. S. Brush, M. H. Elliott, K. R. Davis, A. G. Anderson, R. E. Anderson, Mol. Vision 2010, 16, 1669-1679; c) F. Li, L. D. Marchette, R. S. Brush, M. H. Elliott, Y. Z. Le, K. A. Henry, A. G. An derson, C. Zhao, X. Sun, K. Zhang, R. E. Anderson, Mol. Vision 2009, 15, $1185-1193$.

[8] a) L. Balas, T. Durand, Prog. Lipid Res. 2016, 61, 1-18; b) U. Jahn, J. M. Galano, T. Durand, Angew. Chem. Int. Ed. 2008, 47, 5894-5955; Angew. Chem. 2008, 120, 5978-6041; c) C. N. Serhan, N. A. Petasis, Chem. Rev. 2011, 111, 5922-5943.

[9] a) N. G. Bazan, J. M. Calandria, C. N. Serhan, J. Lipid Res. 2010, 51, 2018 2031; b) P. K. Mukherjee, V. L. Marcheselli, C. N. Serhan, N. G. Bazan, Proc Natl. Acad. Sci. USA 2004, 101, 8491-8496.

[10] G. L. Bannenberg, N. Chiang, A. Ariel, M. Arita, E. Tjonahen, K. H. Gotlinger, S. Hong, C. N. Serhan, J. Immunol. 2005, 174, 4345-4355.

[11] N. G. Bazan, V. L. Marcheselli, K. Cole-Edwards, Ann. N. Y. Acad. Sci. 2005 1053, 137-147.

[12] a) J. M. Galano, E. Mas, A. Barden, T. A. Mori, C. Signorini, C. De Felice, A. Barrett, C. Opere, E. Pinot, E. Schwedhelm, R. Benndorf, J. Roy, J. Y. Le Guennec, C. Oger, T. Durand, Prostaglandins Other Lipid Mediators 2013 107, $95-102$; b) J. Roy, C. Oger, J. Thireau, J. Roussel, O. Mercier-Touzet, D. Faure, E. Pinot, C. Farah, D. F. Taber, J. P. Cristol, J. C. Lee, A. Lacampagne, J. M. Galano, T. Durand, J. Y. Le Guennec, Free Radical Biol. Med. 2015, 86, 269-278.

[13] a) E. K. Long, M. J. Picklo, Sr., Free Radic. Biol. Med. 2010, 49, 1-8; b) F. J. Van Kuijk, L. L. Holte, E. A. Dratz, Biochim. Biophys. Acta Lipids Lipid Metab. 1990, 1043, 116-118.

[14] A. Ishikado, K. Morino, Y. Nishio, F. Nakagawa, A. Mukose, Y. Sono, N. Yoshioka, K. Kondo, O. Sekine, T. Yoshizaki, S. Ugi, T. Uzu, H. Kawai, T. Makino, T. Okamura, M. Yamamoto, A. Kashiwagi, H. Maegawa, PLoS One 2013, 8, e69415.

[15] a) B. G. Gugiu, C. A. Mesaros, M. Sun, X. Gu, J. W. Crabb, R. G. Salomon, Chem. Res. Toxicol. 2006, 19, 262-271; b) C. Schneider, K. A. Tallman N. A. Porter, A. R. Brash, J. Biol. Chem. 2001, 276, 20831-20838; c) C. M. Spickett, Redox Biol. 2013, 1, 145-152.
[16] a) Q. Ebrahem, K. Renganathan, J. Sears, A. Vasanji, X. Gu, L. Lu, R. G. Salomon, J. W. Crabb, B. Anand-Apte, Proc. Natl. Acad. Sci. USA 2006, 103, $13480-13484$; b) J. G. Hollyfield, Invest. Ophthalmol. Visual Sci. 2010, 51 , 1276-1281; c) J. G. Hollyfield, V. L. Perez, R. G. Salomon, Mol. Neurobiol. 2010, 41, 290-298.

[17] a) A. Y. Andreyev, H. S. Tsui, G. L. Milne, V. V. Shmanai, A. V. Bekish, M. A. Fomich, M. N. Pham, Y. Nong, A. N. Murphy, C. F. Clarke, M. S. Shchepinov, Free Radical Biol. Med. 2015, 82, 63-72; b) S. Hill, K. Hirano, V. V. Shmanai, B. N. Marbois, D. Vidovic, A. V. Bekish, B. Kay, V. Tse, J. Fine, C. F. Clarke, M. S. Shchepinov, Free Radical Biol. Med. 2011, 50, 130-138 c) S. Hill, C. R. Lamberson, L. Xu, R. To, H. S. Tsui, V. V. Shmanai, A. V. Bekish, A. M. Awad, B. N. Marbois, C. R. Cantor, N. A. Porter, C. F. Clarke, M. S. Shchepinov, Free Radical Biol. Med. 2012, 53, 893-906; d) C. R Lamberson, L. Xu, H. Muchalski, J. R. Montenegro-Burke, V. V. Shmanai, A. V. Bekish, J. A. McLean, C. F. Clarke, M. S. Shchepinov, N. A. Porter, J. Am. Chem. Soc. 2014, 136, 838-841.

[18] a) P. Brabet, D. Cia, L. Guillou, C. Hamel, C. Vigor, T. Durand, C. Crauste, J. Vercauteren (Centre Hospitalier Universitaire Montpellier, Institut $\mathrm{Na}$ tional de la Sante et de la Recherche Medical, Universite d'Auvergne, Universite Montpellier, France), WO2015162265A1, 2015; b) C. Crauste, C. Vigor, P. Brabet, M. Picq, M. Lagarde, C. Hamel, T. Durand, J. Vercauteren, Eur. J. Org. Chem. 2014, 4548-4561.

[19] a) R. Corberán, M. Sanaú, E. Peris, J. Am. Chem. Soc. 2006, 128, $3974-$ 3979 ; b) G. Kohl, R. Rudolph, H. Pritzkow, M. Enders, Organometallics 2005, 24, 4774-4781; c) M. H. G. Prechtl, M. Holscher, Y. Ben-David, N Theyssen, R. Loschen, D. Milstein, W. Leitner, Angew. Chem. Int. Ed. 2007, 46, 2269-2272; Angew. Chem. 2007, 119, 2319-2322; d) C. M. Yung, M. B. Skaddan, R. G. Bergman, J. Am. Chem. Soc. 2004, 126, $13033-13043$.

[20] G. Erdogan, D. B. Grotjahn, J. Am. Chem. Soc. 2009, 131, 10354-10355.

[21] J. S. Cannon, S. F. Kirsch, L. E. Overman, H. F. Sneddon, J. Am. Chem. Soc 2010, 132, 15192-15203.

[22] R. E. Ireland, L. B. Liu, T. D. Roper, Tetrahedron 1997, 53, 13221-13256.

[23] A. Guy, C. Oger, J. Heppekausen, C. Signorini, C. De Felice, A. Furstner, T. Durand, J. M. Galano, Chem. Eur. J. 2014, 20, 6374-6380.

[24] G. Dayaker, T. Durand, L. Balas, Chemistry 2014, 20, 2879-2887.

[25] C. A. Brown, V. K. Ahuja, J. Chem. Soc. Chem. Commun. 1973, 553-554.

[26] T. Caruso, A. Spinella, Tetrahedron: Asymmetry 2002, 13, 2071-2073.

[27] C. Oger, L. Balas, T. Durand, J. M. Galano, Chem. Rev. 2013, 113, 1313 1350

[28] B. Kang, R. Britton, Org. Lett. 2007, 9, 5083-5086.

[29] K. Mori, T. Ebata, Tetrahedron 1986, 42, $3471-3478$.

[30] T. Itoh, I. Murota, K. Yoshikai, S. Yamada, K. Yamamoto, Bioorg. Med. Chem. 2006, 14, 98-108.

[31] M. G. Jakobsen, A. Vik, T. V. Hansen, Tetrahedron Lett. 2012, 53, 5837 5839.

[32] A. K. Holmeide, L. Skattebol, J. Chem. Soc. Perkin Trans. 1 2000, 2271 2276.

[33] R. Wang, A. He, E. Ramu, J. R. Falck, Org. Biomol. Chem. 2015, 13, 1624 1628.

[34] M. Di Nunzio, V. Valli, A. Bordoni, Int. J. Food Sci. Nutr. 2016, 67, $834-$ 843. 